DOI: 10.32089/WBH.PHW.2020.1(271).0004

orcid.org/0000-0003-4077-8709

BARTŁOMIEJ SZYPROWSKI

\title{
Aresztowanie Jadwigi Kuberskiej „Mei” \\ i Ireny Kalinowskiej „Ludki” oraz likwidacja konfidenta Mieczysława Darmaszka
}

Powołanie i działalność w czasie II wojny światowej w Polsce konspiracyjnych struktur walczących $\mathrm{z}$ okupantem spotkały się z reakcją niemieckich służb policyjnych, która była nastawiona na ich likwidację, w tym poprzez rozpracowanie agenturalne. Okupant oparł się przede wszystkim na informatorach rekrutowanych spośród członków polskiego społeczeństwa, którzy dla własnej korzyści materialnej lub obietnicy ratowania życia skłonni byli działać na szkodę organizacji podziemnych lub polskich obywateli ${ }^{1}$. To wymusiło powołanie w ramach konspiracyjnych struktur wojskowych (Związku Walki Zbrojnej/Armii Krajowej - ZWZ/AK) i cywilnych (Delegatura Rządu na Kraj) wyspecjalizowanych komórek kontrwywiadowczych oraz sądowych, których zadaniem była ochrona organizacji oraz społeczeństwa. 16 kwietnia 1940 r. Komitet dla Spraw Kraju podjął uchwałę o powołaniu Sądów Kapturowych, odrębnych dla organizacji zbrojnej (ZWZ) i Delegatury Rządu na Kraj, których zadaniem było sądzenie spraw karnych dotyczących prześladowców, zdrajców, szpiegów i prowokatorów². Od listopada 1941 r., po wprowadzeniu w życie Statutu Wojskowych Sądów Specjalnych,

\footnotetext{
${ }^{1}$ Skala donosicielstwa wśród obywateli polskich w czasie okupacji nie miała charakteru marginalnego; zob. B. Engelking, Szanowny Panie Gestapo. Donosy do władz niemieckich w Warszawie i okolicach w latach 1940-1941, Warszawa 2012.

${ }^{2}$ Studium Polski Podziemnej w Londynie (dalej: SPP), Sądownictwo wojskowe 1940-1944, sygn. A.3.3.7, Uchwała Komitetu dla Spraw Kraju w sprawie sądów kapturowych, b.m. 16 IV 1940 r., k. 1-2.
} 
w ramach ZWZ/AK działały Wojskowe Sądy Specjalne (WSS)33. Sądy Delegatury Rządu na Kraj, nazywane Cywilnymi Sądami Specjalnymi (CSS), faktycznie działały dopiero od $1942 \mathrm{r}$. i rozpatrywały sprawy podsądnych niebędących żołnierzami AK, dla których właściwe były WSS-y ${ }^{4}$. Zasady działania WSS przewidywały możliwość wydania wyroku już po faktycznej eliminacji osoby zagrażającej organizacji - tzw. likwidacji prewencyjnej, która była uzasadniona okolicznościami zdarzenia oraz tym, że zwłoka konieczna do uzyskania wyroku spowodowałaby straty ludzkie, np. aresztowanie obywateli polskich lub członków organizacji. W takim wypadku sąd post factum badał okoliczności sprawy oraz to czy zabicie osoby bez wyroku było uzasadnione ${ }^{5}$. Jurysdykcji sądów podziemnych podlegali obywatele polscy, którzy działali na szkodę struktur konspiracyjnych oraz innych członków polskiego społeczeństwa.

Przedstawione wyżej informacje wstępne konieczne są, aby można było zrozumieć okoliczności i podstawy prawne zastrzelenia Mieczysława Darmaszka przez członkinie Kobiecych Patroli Minerskich (KPM) Kierownictwa Dywersji (Kedywu) Okręgu Warszawskiego Armii Krajowej. Sprawa Darmaszka była już przedmiotem opracowań o charakterze popularnonaukowym ${ }^{6}$. Opublikowano również część dokumentów i wspomnień poświęconych jego działaniom, a w szczególności zastrzeleniu tego agenta ${ }^{7}$. W powyższej literaturze podnoszono, że zabicie konfidenta 15 marca $1944 \mathrm{r}$. było wynikiem orzeczenia sądu podziemnego. Wydaje się jednak, że tak nie

${ }^{3}$ Archiwum Akt Nowych w Warszawie (dalej: AAN), Armia Krajowa (dalej: AK), sygn. 203/XV-3, Komenda Obszaru Lwów, Statut Wojskowych Sądów Specjalnych, b.m. 27 XI 1941 r., k. 20.

${ }^{4}$ AAN, AK, sygn. 203/VIII-1, Kierownictwo Walki Podziemnej 1942-1944, Statut Sądów Specjalnych, b.m., b.d., k. 28; Rozkaz nr 165 gen. Stefana Roweckiego „Grota”, Organizacja Kierownictwa Walki Podziemnej, b.m. 6 VII 1943 r., k. 12-13.

${ }^{5}$ AAN, AK, sygn. 203/VIII-1, Kierownictwo Walki Podziemnej 1942-1944, Rozkaz nr 165 gen. Stefana Roweckiego „Grota”, Organizacja Kierownictwa Walki Podziemnej, b.m. 6 VII 1943 r., k. 12-13; Archiwum Instytutu Pamięci Narodowej w Warszawie (dalej: AIPN), Ministerstwo Bezpieczeństwa Publicznego w Warszawie [1944] 1945-1954 (dalej: MBP), 1558/400, Armia Krajowa. Okręg Kraków. Inspektorat Miechów, Pismo Konrada Zielińskiego „Karoli”, b.m. 6 III 1944 r., k. 2.

${ }^{6}$ W. Königsberg, AK 75. Brawurowe akcje Armii Krajowej, Kraków 2017, s. 190-192; idem, Zabójcze dziewczyny z AK. Likwidacja Mieczysława Darmaszka, https://ciekawostkihistoryczne.pl/2017/10/23/zabojcze-dziewczyny-z-ak-likwidacja-mieczyslawa-darmaszka/\#3 (dostęp 10 IX 2019).

${ }^{7}$ K. Kurkowska-Bondarecka, Kobiece patrole minerskie Kedywu Okręgu Warszawskiego ZWZ-AK, „Wojskowy Przegląd Historyczny” 1991, nr 3/4 (137/138), s. 98-99; Kedyw Okręgu Warszawskiego Armii Krajowej. Dokumenty - rok 1943, oprac. H. Rybicka, Warszawa 2006, s. 129; Kedyw Okregu Warszawskiego Armii Krajowej. Dokumenty - rok 1944, oprac. H. Rybicka, Warszawa 2009, s. 59. 
było, bowiem wyrok, o ile zapadł, został wydany już po fizycznej eliminacji agenta. $\mathrm{Z}$ uwagi na pewne rozbieżności w literaturze konieczne wydaje się naświetlenie okoliczności, które doprowadziły do tej akcji.

Obecnie mamy niedużą wiedzę o Mieczysławie Darmaszku i jego rodzinie. Wiemy, że urodził się 29 marca 1917 r. ${ }^{8}$ i był synem Aleksandra i Konstancji z domu Garnysz'. Jego ojciec był księgowym. Wiemy, że w 1930 r. jego rodzina mieszkała przy ul. Puławskiej $41 \mathrm{w}$ Warszawie $^{10}$. Konstancja Darmaszek zm. 3 września 1938 r. i została 6 września 1938 r. pochowana na Cmentarzu Bródnowskim w Warszawie. W treści nekrologu nie wymieniono Aleksandra Darmaszka, co może wskazywać na jego uprzednią śmierć ${ }^{11}$. Mieczysław Darmaszek miał również brata Bogusława, który w czasie okupacji pracował jako intendent w V Ośrodku Zdrowia i Opieki Społecznej ${ }^{12}$ przy ul. Miodowej $24 \mathrm{w}$ Warszawie ${ }^{13}$. Prawdopodobnie miał

${ }^{8}$ W meldunku komórki policyjnej 993/P Wydziału Bezpieczeństwa i Kontrwywiadu KG AK wskazano, że Mieczysław Darmaszek urodził się 29 III 1927 r.; zob. AAN, AK, sygn. 203/III-112, Komenda Główna Oddział II, Raport nr 105 „P24/I”, b.m. 16 V 1944 r., k. 19. Prawdopodobnie pomyłka w roku urodzenia (1927) wynika z błędnego przepisania raportu lub ustalenia wywiadowcy.

${ }^{9}$ Nekrolog Konstancji Darmaszek, „Kurier Warszawski”, 4 IX 1938, nr 242. Według meldunku AK nazwisko panieńskie brzmiało Gornysz; zob. AAN, AK, sygn. 203/III-112, Raport nr 105 „P24/I”, b.m. 16 V 1944 r., k. 19.

${ }^{10}$ Książka informacyjno-adresowa „Cała Warszawa”, Warszawa 1930.

${ }^{11}$ Zawiadomienie o śmierci Konstancji Darmaszek podpisali: „Córki, synowie, brat, zięć i rodzina”; zob. Nekrolog Konstancji Darmaszek...; Konstancja Darmaszek, http://www.nekrologi-baza.pl/zlista/67 (dostęp 10 IX 2019). Jej grób znajduje się w kwaterze 54E, rząd 5, miejsce 31; zob. Informacja Zarządu Cmentarza Bródnowskiego w Warszawie do Bartłomieja Szyprowskiego, Warszawa 24 IX 2019 r., w zbiorach autora; Zdjęcie grobu Konstancji Darmaszek, w zbiorach autora.

${ }^{12}$ V Ośrodek Zdrowia i Opieki Społecznej funkcjonował już w 1938 r. i podlegał Zarządowi m. st. Warszawy; zob. „Opiekun Społeczny. Miesięcznik Poświęcony zagadnieniom służby społecznej stolicy” 1938, nr 10 (25), s. 41. W meldunkach AK był on również określany jako V Ośrodek Opieki i Zdrowia oraz V Ośrodek Zdrowia; zob. AAN, AK, sygn. 203/ III-112, Komenda Główna Oddział II, Raport nr 105 „P24/I”, b.m. 16 V 1944 r., k. 19; sygn. 203/X-61, Komenda Obszaru Warszawa. Meldunki i informacje o osobach współpracujących z Gestapo, Meldunek Zofii Franio „Doktor”, Ireny Hahn „Isi” i Antoniny Mijal „Tosi”, b.m. 7 II 1944 r., k. 14; AIPN, Stołeczny Urząd Spraw Wewnętrznych w Warszawie [1944] 1983-1990 (dalej: SUSW), 380/30/1, Działalność wywiadu i kontrwywiadu Armii Krajowej na terenie Warszawy - wykazy konfidentów Gestapo, charakterystyki, informacje, Ostrzeżenie „Madagaskaru”, Warszawa 16 VIII 1943 r., k. 96; Akt oskarżenia Mieczysława Darmaszka z 7 II 1944 r. [w:] Oddział kobiecy warszawskiego Kedywu. Dokumenty z lat 1943-1945, oprac. H. Rybicka, Warszawa 2002, s. 37. Podnoszono również błędnie, że V Ośrodek Zdrowia i Opieki Społecznej był przy ul. Miodowej 23; zob. AAN, AK, sygn. 203/III-112, Komenda Główna Oddział II, Raport nr 105 „P24/I”, b.m. 16 V 1944 r., k. 19.

${ }^{13}$ AAN, AK, sygn. 203/III-178, Komenda Główna Oddział II. Działalność władz niemieckich, kolaborantów 1943-1944, Ostrzeżenia, b.m., b.d., k. 112; AIPN, SUSW, 380/30/1, 


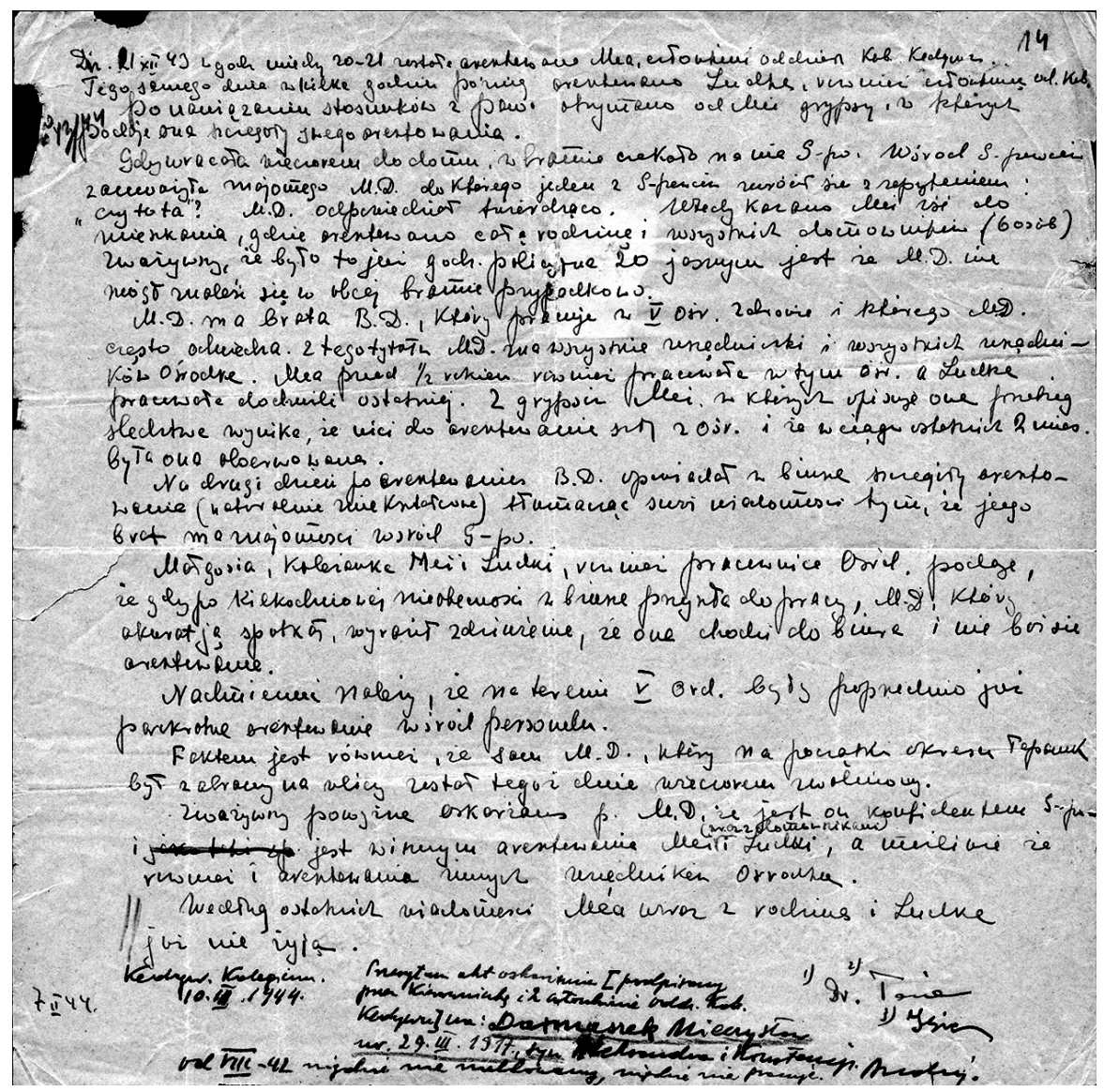

Meldunek „Doktor”, „Isi” i „Tosi” z 7 II 1944 r.

Źródło: AAN, AK, sygn. 203/X-61

również innych braci i siostry ${ }^{14}$. $Z$ dokumentów wynika, że dwaj członkowie jego rodziny byli żołnierzami Narodowych Sił Zbrojnych (NSZ) i walczyli w Powstaniu Warszawskim. W zestawieniu żołnierzy I Brygady Dyspozycyjno-Zmotoryzowanej Komendy Głównej NSZ „Koło” figuruje podchorąży Bogusław Darmaszek „Garnysz”, zaś w kompanii ppor. Leonarda Kancelarczyka „Jeremiego” ze Zgrupowania „Chrobry II” ppor. Wincenty Darmaszek

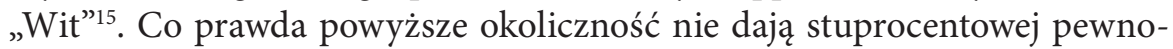
ści, że byli oni spokrewnieni z Mieczysławem Darmaszkiem, lecz wskazuje

Działalność wywiadu i kontrwywiadu Armii Krajowej na terenie Warszawy - wykazy konfidentów Gestapo, charakterystyki, informacje, Ostrzeżenie „Madagaskaru”, Warszawa 16 VIII 1943 r., k. 96.

${ }^{14}$ Nekrolog Konstancji Darmaszek...

${ }^{15}$ Oddziały i żotnierze NSZ w Powstaniu Warszawskim, red. I. Sawicka, Warszawa 1998, s. 57, 267; Wincenty Darmaszek, https://www.1944.pl/powstancze-biogramy/ 


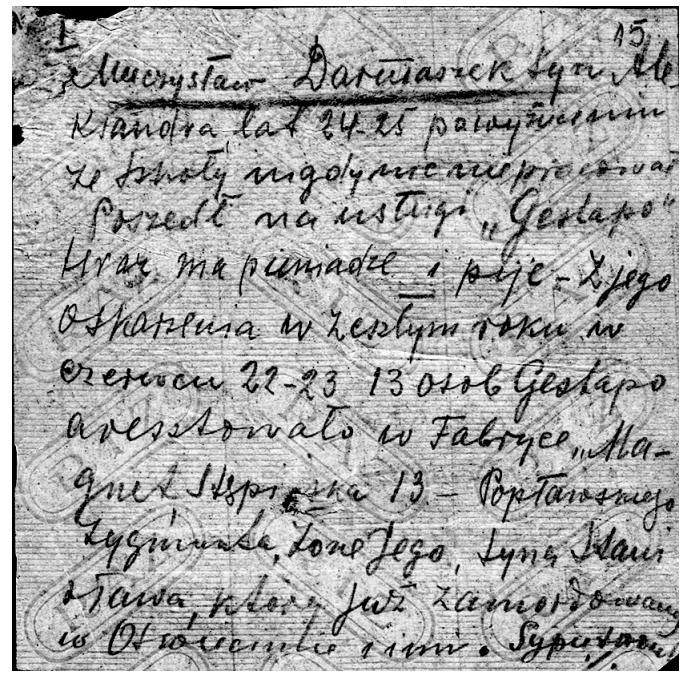

Raport dot. Mieczysława Darmaszka Źródło: AAN, AK, sygn. 203/X-61

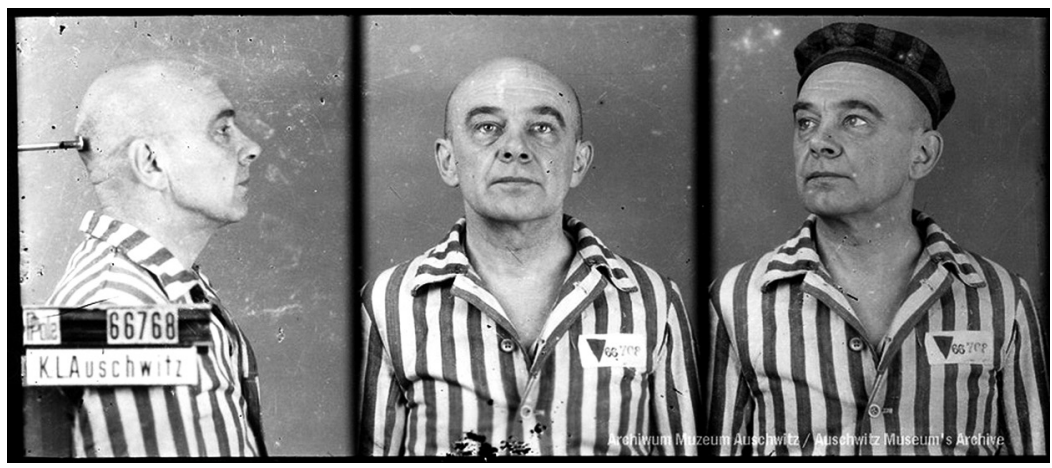

Zygmunt Popławski

Źródło: zdjęcie ze zbiorów Archiwum Państwowego Muzeum Auschwitz-Birkenau w Oświęcimiu

na to nie tylko zbieżność nazwisk, ale również fakt, że według dokumentów źródłowych Bogusław Darmaszek był zapatrywań narodowych ${ }^{16}$. Nadto siostra Mieczysława - Jadwiga Darmaszek-Sasiak - była sanitariuszką Sanitariatu Okręgu Warszawskiego AK (krypt. „Bakcyl”)"

wincenty-darmaszek,7510.html?fbclid=IwAR28vU_YFJQXV4v0iUnQqoxHs16tCAPsp-z8rdYKKDONm0t81OfFeJM2I_4 (dostęp 17 IX 2019).

${ }^{16}$ Bogusław Darmaszek był przed wybuchem II wojny światowej członkiem Obozu Narodowo-Radykalnego; zob. AAN, AK, sygn. 203/X-61, Komenda Obszaru Warszawa. Meldunki i informacje o osobach współpracujących z Gestapo, Meldunek ppor. Edmunda Odorkiewicza „Liwa”, b.m., b.d., k. 13; Nowa secesja z ozonowego Z.M.P., „Czas”, 6 V 1938, nr 123, s. 4 .

${ }^{17}$ Jadwiga Darmaszek-Sasiak, https://www.1944.pl/powstancze-biogramy/jadwiga-darmaszek,7509.html?fbclid=IwAR3CpMPC8eveBjhORkDg9YvvvKtAxIeODCLVMsYKwrGqMy4FzZuHExUDTdA (dostęp 17 IX 2019). 
$-4-$

12/.DARMASZKK MIECZYSEAW ur.29.III.1917 r.s.Aleksandra 1 Kongtancjs,n1gdz1e nie pracuje, wymeldowany 20 .VIII. $1946 \mathrm{r.z}$ ul. Szustra $20 \mathrm{~m} .9$ na wj. Chonie pracuje, wy ale tam nie zameldowany. Moouje w lokalu nr.57 przy ul. M10 cimska 13 m. dowej 24 u PIontowe na prawo kolo windy, ostatnie pietro t.zw.erajaty. DAPHASZHK Irontowego na prawe koło windy,ostatnie pietro t.zw. Iacjaty. DARUASZ Rysopis:wzrost sredn1, c1 smowkony, szczup'y, przystojny. Brat jego BOGT SY,AW DAFNASZIK pracuja jeko intendent $V-a$ Osrodka Zdrovia 1 Opleki wl. Wodowa DAFNASZAK pracuja jako intendenta do Óśodka, a zw Xaszeza ma to miejsce 24. N. D. przychodzi często do brata do osrodka, a zw xaszcza ma Wiosna 42 r.g-o przvggło po k frownika tego Óśodka.Szczésilvym trafen nd zastali 80 w esrodku, musiał zniknǵ̨. urzędnicgki tego Ośrodka jedna o godz.1 po wyjuclu z biura, druga o tej sa mej porze Iub troche. póniej w otwocku, sazie ozasowo przebywała.0 adregie jej Otwocku wiedziało tylko kilka osób z ósodka.Znaleziono przy nich materaił ì obydwie zostaxy gesłane do Oswięcimia.Pracovały razem. Dnie 2I.XII.42 r. aresztowana by Za w mieszkaniu przy uI. Miodowej 23 była urzędniczka ósrodka J.K.wraz z nią aresztowane były jej 2 siostry.0jciec i 2 nooujących mężzyzn. ednocześnie aresztowana była przy ul.Zakroozymskiej druga urzedniczka ośrodka I.K.współpracujaca z J.K.Wszystkie te osoby zostały rozstrzelane w lutym $43 \mathrm{r}$. Tego samego wieczoru o godz. 11,30 juz po aresztowaniu J.K. I I.K. M.DAPMASZkK przyszedz pijany pod dom $n x$. 24 przy Miodowej.Odprowadzili go zandarmi 1 kazal1 dozoroy wpuślé go do domu. Widzieli to pracownicy ośrodka którzy tego wieczora miell dyźur opl. Po aresztowaniu I. K. DAPMASZBK zaofiarował rodzinle aresztowanej reekome pomoc obiecując interwenlowat 1 wykorzvstá swoje znajomośc1. Wy zudzil od nich ok.7 tys.zł. Allesztowana została rozatrzelana 1 jak sie pónlej okaze to nikt w jej sprawie nie interwenlowa?.

W okreste niedawnyoh mssowych aresztowaí na vilcach aresztowany by 1 ou kiern1 K.D.wraz z kilkome młodym1 lud drugi dzien a pozostałych rozstrzelano. Mbwil o tym brat $M$. D.

Znajomi wyrazają sie o M. D, 1 jego bracie twierdząo te sa to konfldonol. kanalje,którym zadny porząiny czlowiek nie powinien podawa relci.2 tego samego Éródza donosżą że w jednym z mieszká w W-wie zostero znalezlone radio.Aresztowany zostaz własololol lokalu 1 jego syn. Gay ktoś vyraz1? zdziwienie ze malaziono tak dobrze ukrvta rzecz, a rubrca kt ra bvra śriad kiem rewizj1 i areaztowania powledzlała; "nio dzimego, przeciet a niml by?

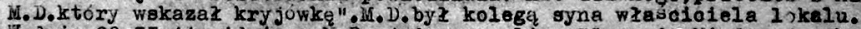
17 dniu 29.II.44.w1dzlano If. D. jadącego vilea Długt do Mlodowej odkrytym olęzarowym samochódem wraz 8 uzbrojonymi żandarnami. Wazysey w mundur oh, on jeden po oywilnemu. Inać by $x o$ ze jechall sdzles na robotę.

Dnta 2. III.44.0 godz.19 M.D.przyszed? pljany do 0srodka 1 kykrzykiwaz * obecnoác1 kilku młodych D acown lków Ośrodka będących na dyzurze 0p1, "Wier zo wszysoy jesteśoie podchorązakam1, wesgstkim was oddam s-o "przyczyr wymieniaz obecnych imiennie.

Brat $M_{0}$ D. ostrzegax niedawno jednego a pracounlkbw zeby nle praychodziz wozénle do Ośrodka i nie gledrlał wieczorami. Oatrzezente to zroblone by? oozfwiscle na efekt w dowód rzekomej zyozliwosiol.

Istnieje opinfa że B.D.śwladomle cry nieśwladomie sbiera materlał a $\mathrm{M}, \mathrm{D}$ materiał ten wykorzystufe subląo oaly szereg ludzi, W kazd, m z wypadkb. aresztowań B.D.wiedzlaz ze el ludzle pracuja a M.D.znat lah dobrzo. Wypadki arasztowaí pracownikón ósrodka zawszo traflazy wo wrasolwe alejac 1 verynione by $3 y$ we w2aselwym ozasie, znad by by $¥ y$ dokładne informacje. W Osrodku panuje atmosfere Ieksa, pracownior boja ile przychodzió do praoy spadziewejąe blę od dzlen nowyohwy padrón.

ZAKZAD MEZYYCYNY SADOFIBJ.

Krasuak1 ? gastrz.1.IIT.44.0kopowa 25

Pixatowioz Roman zastrz.1. III. Leszno.

Duda Hiexonim, zastrz.2. III. vi, kiedziana.

Kurełek Zdziskaw, zastrz.2.III.j an Bozy.

Raport specjalny nr 12/44 z 21 III 1944 r.

Źródło: AAN, AK, sygn. 203/X-100

Mieczysław Darmaszek w czasie okupacji prawdopodobnie przez pewien okres pracował na robotach przymusowych w III Rzeszy, a następnie powrócił do Warszawy ${ }^{18}$. Być może przez jakiś czas mieszkał wspólnie z bratem Bogusławem, który do 20 sierpnia 1942 r. był zameldowany przy ul.

${ }^{18}$ Lista wyroków zleconych do wykonania oddziałom Kedywu Okręgu AK Warszawa (lata 1943-1944) [w:] Kedyw Okręgu..., Dokumenty - rok 1943..., s. 129; AAN, AK, sygn. 203/X-61, Komenda Obszaru Warszawa. Meldunki i informacje o osobach współpracujących z Gestapo, Raport, b.m., b.d., k. 19. 


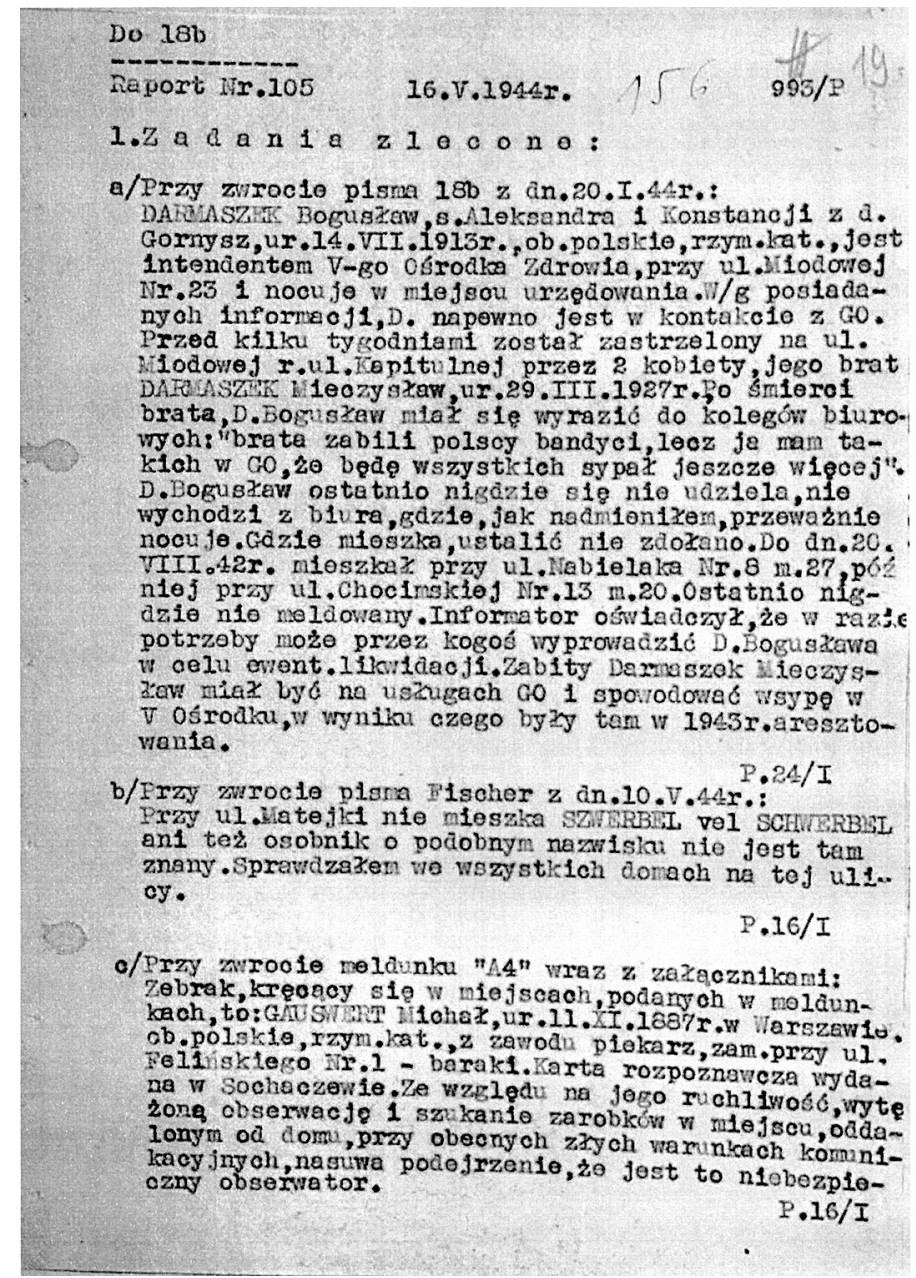

Raport nr 105 „P24/I” z 16 maja 1944 r.

Źródło: AAN, AK, sygn. 203/III-112, Komenda Główna Oddział II, k. 19

Nabielaka 8/27, a później przy ul. Chocimskiej 13/2019. Jednak z innego meldunku wynikało, że Mieczysław Darmaszek do 20 sierpnia 1942 r. mieszkał przy ul. Szustra 20/9, skąd został wymeldowany na ul. Chocimską 13/20, lecz tam nie przebywał ${ }^{20}$. Nie był nigdzie zameldowany i przenosił się z miejsca

${ }^{19}$ AAN, AK, sygn. 203/III-112, Komenda Główna Oddział II, Raport nr 105 „P24/I”, b.m. 16 V 1944 r., k. 19; AIPN, MBP, 1558/45, Komenda Główna Armii Krajowej. Oddział II Informacyjno-Wywiadowczy. Wydział Bezpieczeństwa i Kontrwywiadu „Wd-69”, Konfidenci, b.m. 2 VIII 1943 r., k. 211.

${ }^{20}$ AAN, AK, sygn. 203/X-100, Komenda Obszaru Warszawa, Rozpracowania, sprawozdania i raporty specjalne nr 2-15/44 dot. Niemców, kolaborantów i komunistów 3 I 1944 r. 25 VII 1944 r., Raport specjalny 12/44, b.m. 21 III 1944 r., k. 113; AIPN, MBP, sygn. 1558/45, 
na miejsce. W 1944 r. nocował u pani Pilatowskiej przy ul. Miodowej 24/5721. W kronice policyjnej odnotowano również, że w chwili śmierci mieszkał przy ul. Ząbkowskiej $2 \mathrm{w}$ Warszawie ${ }^{22}$.

Opisywano go jako mężczyznę w wieku 20-21 lub 24-25 lat, wysokiego wzrostu, szczupłego, ciemnego blondyna o bardzo jasnej, różowej cerze ${ }^{23}$.

Już w 1943 r. działalność agenturalna Mieczysława Darmaszka została odnotowana przez służbę kontrwywiadowczą AK. Informowano: „Mieczysław Darmaszek syn Aleksandra lat 24-25 po wyrzuceniu ze szkoły nigdzie nie pracował. Poszedł na usługi Gestapo. Teraz ma pieniądze i pije. Z jego oskarżenia w zeszłym roku w czerwcu (22-23) 13 osób Gestapo aresztowało w Fabryce «Magnet» Stępińska 13 - Popławskiego Zygmunta, żonę jego, syna Stanisława, który już zamordowany w Oświęcimiu ${ }^{24}$ i inni. Sypnął też kolegów ze szkoły, z klubu piłki nożnej «Polonia» i nie ma dnia, żeby nie aresztowali Polaków. Oprócz fabryki w Mokotowie wydał syna piekarza [nieczytelne] Kwiatkowskiego. Już 8 osób nie żyje, reszta kona w Oświęcimiu [...]. Nocami grywa w kasynie na Szucha ${ }^{25}$, dniami bywa na sali bilardowej

Komenda Główna Armii Krajowej. Oddział II Informacyjno-Wywiadowczy. Wydział Bezpieczeństwa i Kontrwywiadu „Wd-69”, Konfidenci, b.m. 2 VIII 1943 r., k. 211.

${ }^{21}$ AAN, AK, sygn. 203/X-61, Komenda Obszaru Warszawa. Meldunki i informacje o osobach współpracujących z Gestapo, Raport, b.m., b.d., k. 19; sygn. 203/X-100, Komenda Obszaru Warszawa, Rozpracowania, sprawozdania i raporty specjalne nr 2-15/44 dot. Niemców, kolaborantów i komunistów 3 I 1944 r. - 25 VII 1944 r., Raport specjalny 12/44, b.m. 21 III 1944 r., k. 113; AIPN, SUSW, 380/30/2, Działalność wywiadu i kontrwywiadu Armii Krajowej na terenie Warszawy - wykazy konfidentów Gestapo, charakterystyki, informacje, Meldunek Stanisława Babiarza „Wysockiego” do „Madagaskaru”, Warszawa 16 VIII 1943 r., k. 100; Ostrzeżenie „Madagaskaru”, b.m. 16 VIII 1943 r., k. 100; MBP, 1558/45, Komenda Główna Armii Krajowej. Oddział II Informacyjno-Wywiadowczy. Wydział Bezpieczeństwa i Kontrwywiadu „Wd-69”, Konfidenci, b.m. 2 VIII 1943 r., k. 211; Lista wyroków zleconych... [w:] Kedyw Okregu..., Dokumenty - rok 1943..., s. 129. „Madagaskar” był jednym z kryptonimów 7 pp AK „Garłuch”; zob. J. Kulesza, Garłuch. Opowieść o 7. pułku piechoty AK w konspiracji i Powstaniu Warszawskim, Warszawa 2014, s. 14, 26.

${ }^{22}$ H. Witkowski, Kedyw Okręgu Warszawskiego Armii Krajowej w latach 1943-1944, Warszawa 1985, s. 307.

${ }^{23}$ AAN, AK, sygn. 203/X-61, Komenda Obszaru Warszawa. Meldunki i informacje o osobach współpracujących z Gestapo, Raport, b.m., b.d., k. 15; AIPN, MBP, 1558/45, Komenda Główna Armii Krajowej. Oddział II Informacyjno-Wywiadowczy. Wydział Bezpieczeństwa i Kontrwywiadu „Wd-69”, Konfidenci, b.m. 2 VIII 1943 r., k. 211. We wspomnieniach przedstawiano go również jako bruneta; zob. AAN, Komisja Historii Kobiet w walce o Niepodległość (dalej: KHK), Teczka Jadwigi Kuberskiej, sygn. II-K-55, Anna Litwinowiczowa, Notatka „Siostry Kuberskie”, Warszawa 8 IX 1976 r., s. 1, mps.

${ }^{24} \mathrm{~W}$ tym wypadku chodzi o niemiecki obóz koncentracyjny (Konzentrazionslager) Auschwitz-Birkenau.

${ }^{25}$ Kasyno Gry dla Polaków mieściło się w budynku dawnego Kasyna Garnizonowego przy al. Szucha 29 w Warszawie. Było ono prowadzone przez Niemców. Polskie Państwo 
Nowy Świat $5 \mathrm{w}$ restauracji niemieckiej. Ostatnio był meldowany na Narbutta obecnie nieuchwytny [...]. Pomsta do Boga woła za jego codzienne zbrodnie. Wszystkie osoby aresztowane są mi [z] nazwiska znane, lecz z braku miejsca nie mogę ich tu pomieścić. Jego 3 [odwiedzane] punkty: Nowy Świat 5 na bilardach, Miodowa Magistrat u brata [...], wyścigi na Marszałkowskiej przy pl. Unii Lubelskiej"26.

Meldunek, obejmujący zestawienie osób pozostających w rozpracowaniu kontrwywiadu na 2 sierpnia 1943 r., podnosił, że „Darmaszek Mieczysław [...] wydał G[estap]o całą rodzinę swoich krewnych Stasiaków (mieszkali przy ul. Chełmskiej) - kilku mężczyzn wysłano do Oświęcimia. Współpracuje z G[estap]o" ${ }^{\prime 27}$.

W kolejnym raporcie z 16 sierpnia 1943 r. wskazywano: „Ostrzegamy przed następującymi osobami [...]. Osoby podejrzane [...] 12/ Darmaszek Mieczysław, umieszczany już w ostrzeżeniach naszych. Często bywa w biurze u brata swego Bogusława Darmaszka przy ul. Miodowej 24 V Ośrodek Zdrowia i Opieki"28. W 1944 r. podnoszono, że często odwiedzał brata w V Ośrodku, zwłaszcza tuż przed aresztowaniami osób tam pracujących ${ }^{29}$. Zarzucano mu również wydanie mężczyzny ukrywającego radio. Darmaszek był jego znajomym i wskazał kryjówkę. Informowano także,

Podziemne starało się wpajać powinności obywatelskie Polakom pod okupacją m.in. poprzez zakaz uczęszczania do ww. kasyna, bowiem bywanie tam uznawano za formę kolaboracji z Niemcami i wykroczenie przeciwko moralności i godności obywatelskiej. Przykładowo, Władysław Symonowicz „Mirski” z Okręgu Warszawskiego AK zakazywał elewom szkoły podchorążych AK uczęszczania do kasyna, kin, teatrów. Podnosił przy tym: „Zachowanie nasze musi być [...] nacechowane bezwzględną pogardą wobec wroga i wobec wszystkiego, co jest jego wytworem". 19 V 1942 r. podziemie przeprowadziło zamach bombowy na ww. kasyno; zob. AAN, AK, sygn. 203/VIII-1, Kierownictwo Walki Podziemnej 1942-1944, Akcja ogólna, b.m., b.d., k. 4; Kodeks moralności obywatelskiej, b.m., b.d., k. 40; Rozkaz nr 2 Władysława Symonowicza „Mirskiego”, 23 III 1942 r. [w:] Okręg Warszawa-Miasto ZWZ i Okreg Warszawski ZWZ-AK. Dokumenty 1940-1943. Archiwum „Drapacza” ze skrzynki "Ali”, t. II, oprac. M. Olczak, M. Strok, Warszawa 2018, s. 192; T. Strzembosz, Akcje zbrojne podziemnej Warszawy 1939-1944, Warszawa 1983, s. 128-129.

${ }^{26}$ AAN, AK, sygn. 203/X-61, Komenda Obszaru Warszawa. Meldunki i informacje o osobach współpracujących z Gestapo, Raport, b.m., b.d., k. 15.

${ }^{27}$ AIPN, MBP, 1558/45, Komenda Główna Armii Krajowej. Oddział II Informacyjno-Wywiadowczy. Wydział Bezpieczeństwa i Kontrwywiadu „Wd-69”, Konfidenci, b.m. 2 VIII 1943 r., k. 211.

${ }^{28}$ AIPN, SUSW, 380/30/2, Działalność wywiadu i kontrwywiadu Armii Krajowej na terenie Warszawy - wykazy konfidentów Gestapo, charakterystyki, informacje, Meldunek Stanisława Babiarza „Wysockiego” do „Madagaskaru”, Warszawa 16 VIII 1943 r., k. 100; Ostrzeżenie „Madagaskaru”, b.m. 16 VIII 1943 r., k. 100.

29 AAN, AK, sygn. 203/X-100, Komenda Obszaru Warszawa, Rozpracowania, sprawozdania i raporty specjalne nr 2-15/44 dot. Niemców, kolaborantów i komunistów 3 I 1944 r. - 25 VII 1944 r., Raport specjalny 12/44, b.m. 21 III 1944 r., k. 113. 
że 29 lutego 1944 r. jechał w samochodzie z umundurowanymi żandarmami, w celu dokonania aresztowań. 2 marca $1944 \mathrm{r}$., gdy przebywał na terenie V Ośrodka, będąc pod wpływem alkoholu, krzyczał, że wszystkich pracowników wyda w ręce Gestapo, bo są w tajnej podchorążówce ${ }^{30}$.

W meldunku z 9 marca 1944 r. „Lwowiak” (NN) podnosił: „D[armaszek] M[ieczysław] kawaler, lat około 30, nigdzie nie pracuje, b.[ardzo] często jest w stanie nietrzeźwym, głośno mówi o swoich możliwościach w gestapo. Mieszka przy ul. Miodowej $24 \mathrm{z}$ bratem. Ostatnio wyraził się w obecności mego informatora: «Muszę w najbliższym czasie zlikwidować tą polską podchorążówkę w naszym domu». Brat jego pracuje [w] ww. domu jako intendent V Ośrodka Zdrowia, jednocześnie jest k[omendan]tem OPL [...]. W tym samym domu mieszka Politowska Wanda wraz z sublokatorką I. [...] - panie te są w b. zażyłych stosunkach z D[armaszkiem] M[ieczysławem] bywają często razem w Kasynie Gry" ${ }^{31}$. O jego działalności agenturalnej jako konfidenta „Z Miodowej 24” informowała Brygada „C”. Był również odnotowany w kronice policyjnej, prowadzonej przez kontrwywiad Okręgu Warszawskiego $\mathrm{AK}^{32}$.

Z uwagi na zbyt ogólne sformułowania meldunków, dotyczących wydania $\mathrm{w}$ ręce niemieckie rodziny Stasiaków ${ }^{33}$, aresztowania za posiadanie radia oraz zatrzymania Kwiatkowskiego, nie można poczynić w tym zakresie bliższych ustaleń. Dalsze losy aresztowanych członków rodziny Popławskich można prześledzić na podstawie wspomnień i kartotek obozowych i więziennych. Zygmunt Popławski był właścicielem firmy „Magnet” i żołnierzem

${ }^{30}$ Ibidem.

${ }^{31}$ AAN, AK, sygn. 203/X-61, Komenda Obszaru Warszawa. Meldunki i informacje o osobach współpracujących z Gestapo, Raport „Lwowiaka” [NN], b.m. 9 III 1944 r., k. 17.

${ }^{32}$ Ibidem, Raport Anny Rószkiewicz-Litwinowiczowej „Lali”, b.m. 9 III 1944 r., k. 17. Brygada "C” kontrwywiadu Okręgu Warszawskiego AK, dowodzona przez Stefana Olesiaka „Słonia”, pełniła funkcje osłonowe i likwidacyjne; zob. W. Bułhak, A. K. Kunert, Kontrwywiad podziemnej Warszawy. Struktura, zadania i obsada personalna kontrwywiadu Komendy Głównej, Obszaru Warszawa i Okręgu Warszawa ZWZ-AK w latach 1939-1944 [w:] Wywiad i kontrwywiad Armii Krajowej, red. W. Bułhak, Warszawa 2008, s. 364.

${ }^{33}$ Wobec braku podania w meldunku imion mężczyzn z rodziny Stasiaków trudno obecnie zweryfikować ich pobyt w KL Auschwitz-Birkenau. Niemniej jednak z Pawiaka transportem do tego obozu 18 IV 1942 r. został wysłany Bronisław Stasiak (nr 31309), który w 1943 r. został przeniesiony do KL Buchenwald. Pozostali więźniowie KL Auschwitz o tym nazwisku nie zostali przywiezieni z Warszawy; zob. Informacja o więźniach, http://auschwitz.org/ muzeum/informacja-o-wiezniach/ (dostęp 10 IX 2019). Wyszukiwarka więźniów na stronie internetowej Muzeum Auschwitz-Birkenau cytowana dalej jako Informacja o więźniach... (dostęp w dn. 10 i 27 IX 2019); Z. Śliwicki, Meldunek z Pawiaka, Warszawa 1974, s. 304; R. Domańska, Pawiak więzienie gestapo. Kronika 1939-1944, Warszawa 1978, s. 217. Brak bliższych danych uniemożliwia jednak stwierdzenie, czy wskazana powyżej osoba była tą, którą wydał Niemcom M. Darmaszek. 
AK. W pomieszczeniach jego przedsiębiorstwa przechowywano broń i prasę konspiracyjną. Został zatrzymany na skutek donosu 22 czerwca 1942 r. wraz z żoną Marią, synem Stanisławem i córką Ireną oraz jedenastoma pracownikami firmy ${ }^{34}$. 29 września 1942 r. Stanisław i Zygmunt Popławscy zostali wywiezieni do KL Auschwitz ${ }^{35}$. Oznaczono ich odpowiednio numerami: 66767 i 66768. Obaj zostali rozstrzelani: Zygmunt - 10 listopada 1942 r., a Stanisław - 25 listopada 1942 r. ${ }^{36}$ Maria Popławska 12 października 1942 r. została wysłana transportem do obozu KL Auschwitz, gdzie oznaczono ją numerem 22541. Zginęła tam 16 kwietnia $1943 \mathrm{r}^{37} \mathrm{~W}$ odniesieniu do córki Ireny nie dysponujemy informacjami o jej dalszym losie. Nie wiadomo również, pod jakim nazwiskiem została aresztowana. W kartotece Pawiaka występuje Irena Popławska zatrzymana 22 czerwca $1942 \mathrm{r}^{38}$ Jednak we wspomnieniach Zygmunta Śliwińskiego figuruje ona jako Irena Jakubowska, którą po niedługim czasie zwolniono z więzienia ${ }^{39}$. Z drugiej strony Regina Domańska twierdziła, że 5 października 1942 r. Irena Jakubowska została z Pawiaka wywieziona w nieznanym kierunku ${ }^{40}$.

Przyczyną likwidacji Mieczysława Darmaszka było wydanie w ręce niemieckie członkiń KPM Kedywu Okręgu Warszawskiego AK, Ireny Kalinowskiej „Ludki” i Jadwigi Kuberskiej „Mei”. Od chwili powstania struktur konspiracyjnych zadania wykonywane przez kobiety ograniczano do działań w zakresie propagandy, kolportażu prasy podziemnej, łączności, transportu i służby sanitarnej, jednak już w rozkazie nr 51 gen. Stefana Roweckiego z 30 października 1941 r. określono, że kobiety mogą brać udział m.in. w zadaniach dywersyjnych, wywiadowczych i propagandowych ${ }^{41}$. Niemniej

${ }^{34}$ Z. Śliwicki, Meldunek..., s. 272; L. Wanat, Za murami Pawiaka, Warszawa 1985, s. 451.

${ }^{35}$ R. Domańska, Pawiak..., s. 256; L. Wanat, Za murami..., s. 451.

${ }^{36}$ L. Wanat, Za murami..., s. 451; Stanisław Popławski urodził się 16 IV 1921 r.; zob. Stanisław Popławski, http://www.muzeum-niepodleglosci.pl/pawiak/kartoteka-online/?id=26196 (dostęp 27 IX 2019); zob. też Informacja o więźniach...; Zygmunt Popławski, http://www. muzeum-niepodleglosci.pl/pawiak/kartoteka-online/?id=18318 (dostęp 27 IX 2019); zob. też Informacja o więźniach...

${ }^{37}$ Maria Popławska urodziła się 15 X 1890 r.; zob. Maria Popławska, http://www.muzeumniepodleglosci.pl/pawiak/kartoteka-online/?id=25992 (dostęp 27 IX 2019); zob. też Informacja o więźniach...; R. Domańska, Pawiak..., s. 261; Księgi zgonów z Auschwitz. Fragmenty. Indeks nazwisk, cz. 3, Monachium - Paryż 1995, s. 957.

${ }^{38}$ Irena Popławska, http://www.muzeum-niepodleglosci.pl/pawiak/kartoteka-online/?id=25991 (dostęp 27 IX 2019).

39 Z. Śliwicki, Meldunek..., s. 272.

${ }^{40}$ R. Domańska, Pawiak..., s. 259.

${ }^{41}$ SPP, Oddział VI Sztabu Naczelnego Wodza, sygn. A 309, Wojskowa Służba Kobiet, Rozkaz Komendanta Sił Zbrojnych w Kraju, b.m. 30 X 1941 r., k. 3; A. Marcinkiewicz-Kaczmarczyk, 
jednak KPM, dowodzone przez dr Zofię Franio „Doktor”, powołano już w marcu 1940 r. Do 1942 r. działały one w ramach "Związku Odwetu”, współpracując z Biurem Badań Technicznych, dowodzonym przez por. Zbigniewa Lewandowskiego „Szynę” (pierwszy patrol doświadczalno-bojowy dowodzony przez Irenę Bredel „Alinę”), zaś od listopada 1942 r. wchodziły w skład Kedywu Okręgu Warszawskiego AK. KPM były oddziałem dyspozycyjnym dowódcy Kedywu Okręgu Warszawskiego mjr. Jerzego Lewińskiego „Chuchry”, a po jego aresztowaniu 6 listopada 1943 r. - ppor. Józefa Rybickiego „Andrzeja"42. W 1943 r. w skład KPM, oprócz patrolu „Aliny”, wchodziły patrole dowodzone przez: Janinę Geller „Ninę”, Irenę Hahn „Isię”, Wandę Kinstler „Bogumiłę”, Jadwigę Kuberską „Meę”, Antoninę Mijal „Tosię”, Marię Ocetkiewicz „Zosię Saską”, Kazimierę Olszewską „Mirę” i Letę Ostrowską „Justynę”. Od 1942 r. działania bojowe KPM dotyczyły przede wszystkim dezorganizowania wrogiego transportu (wysadzanie mostów i torów kolejowych) ${ }^{43}$ oraz łączności (niszczenie studzienek telekomunikacyjnych). Ponadto KPM uczestniczyły w produkcji uzbrojenia saperskiego, biorąc udział w próbnych wysadzaniach produkowanych materiałów minerskich oraz zajmując się transportowaniem i magazynowaniem broni i materiałów wybuchowych ${ }^{44}$.

Jadwiga Kuberska „Mea”, ur. 21 maja 1912 r., była przed wybuchem II wojny światowej studentką ostatniego roku Szkoły Głównej Handlowej ${ }^{45}$.

Żeńskie oddzialy sabotażowo-dywersyjne $w$ strukturach armii podziemnej w latach 1940-1944 na podstawie relacji i wspomnień ich członkiń, „Pamięć i Sprawiedliwość” 2015, nr 2 (26), s. 120 .

${ }^{42}$ Fundacja Generał Elżbiety Zawadzkiej w Toruniu (dalej: FGEZ), Teczka Zofii Franio, sygn. 74/WSK, Relacja Zofii Franio, Londyn 15 IX 1971 r., k. 5; A. Marcinkiewicz-Kaczmarczyk, Żeńskie oddziały..., s. 121; M. Ney-Krwawicz, Komenda Główna Armii Krajowej 1939-1945, Warszawa 1990, s. 124; K. Wysoczyńska, Zofia Franio. W służbie ojczyźnie, w służbie człowiekowi, Gdańsk 2018, s. 52-59, 64-65.

${ }^{43}$ Patrole KPM uczestniczyły m.in. 8 X 1943 r. w akcji „Wieniec” przeprowadzonej na warszawskim węźle kolejowym (patrole „Isi” i „Tosi” zniszczyły tory kolejowe koło Pyr) i 17 XI 1943 r. w akcji „Odwet kolejowy” - na linii kolejowej Dęblin-Łuków-Brześć (patrol „Miry” zniszczył tor kolejowy koło Łapiguza pod Łukowem); zob. A. Marcinkiewicz-Kaczmarczyk, Żeńskie oddziały..., s. 127.

${ }^{44}$ AAN, KHK, Teczka Ireny Bredel, sygn. II-B-31, Letycja Ostrowska, Relacja Irena Bredel ps. „Alina”, b.m. 8 V 1986 r., s. 1; Teczka Wandy Kinstler, sygn. II-K-13, Kwieta Kurkowska-Bondarecka, Relacja „Bogumiła” - Wanda Kinstler, b.m. 31 III 1990 r., s. 54-55; Teczka Barbary Matys, sygn. II-W-24, Kazimiera Olszewska, Relacja Wysiadecka Barbara zd. Matys ps. „Baśka”, b.m. 6 II 1970 r., s. 1; FGEZ, Teczka Ireny Bredel, sygn. 29/WSK, Janina Bredel, „Relacja o nieżyjącej peowiaczce”, b.m. 14 VII 1970 r., k. 2; A. Marcinkiewicz-Kaczmarczyk, Żeńskie oddziały..., s. 122, 123.

${ }^{45}$ AAN, KHK, Teczka Jadwigi Kuberskiej, sygn. II-K-55, Anna Litwinowiczowa, Notatka „Siostry Kuberskie”, Warszawa 8 IX 1976 r., s. 1, mps. 
W czasie okupacji pracowała w V Ośrodku Zdrowia i Pomocy Społecznej jako opiekunka społeczna ${ }^{46}$. Od listopada 1941 r. była żołnierzem ZWZ - służąc w KPM, gdzie początkowo pełniła funkcję łączniczki. Od marca 1943 r. była dowódcą patrolu i kierownikiem transportu materiałów minerskich ${ }^{47}$. Stałe magazyny pod jej opieką mieściły się w: ruinach Teatru Wielkiego, koszarach „Czwartaków” przy ul. Zakroczymskiej 4 i ruinach domu przy ul. Przemysłowej 8 . Oprócz tego zajmowała się magazynami podręcznymi, które okresowo tworzono w różnych punktach miasta ${ }^{48}$. Według Kwiety Kurkowskiej-Bondareckiej patrolowi Jadwigi Kuberskiej, z uwagi na sumienność i obowiązkowość jego dowódcy, powierzono „pieczę nad magazynami materiałów wybuchowych i innych minerskich środków bojowych pozostających w dyspozycji «Kedywu» Okręgu Warszawskiego"49.

Irena Kalinowska „Ludka”, ur. w 1915 r., była żołnierzem AK od sierpnia 1943 r. w patrolu „Mei” ${ }^{50}$. Prowadziła magazyn broni i materiałów wybuchowych przy ul. Przemysłowej $8 \mathrm{w}$ Warszawie ${ }^{51}$. W innej publikacji podnoszono, że Jadwiga Kuberska w 1942 r. objęła dowództwo patrolu, a „Ludka” została jej zastępcą po wstąpieniu do oddziału w 1943 r. ${ }^{52}$

Analizując źródła dotyczące daty aresztowania Jadwigi Kuberskiej oraz zatrzymanych osób, natrafiamy na pewne rozbieżności. Wojciech Königsberg nie sprecyzował jej, podnosząc, że nastąpiło ono kilka dni przed świętami Bożego Narodzenia 1943 r. $^{53}$

Według Kwiety Kurkowskiej-Bondareckiej aresztowanie nastąpito 23 grudnia 1943 r. Tego dnia w mieszkaniu przy ul. Emilii Plater 20,

\footnotetext{
${ }^{46}$ Ibidem.
}

${ }^{47}$ Ewidencja personalna oddziału kobiecego Kedywu Okręgu AK Warszawa, 15 VI 1944 r. [w:] Oddział kobiecy..., s. 43; H. Michalska et al., Słownik uczestniczek walki o niepodległość Polski 1939-1945. Poległe i zmarłe w okresie okupacji niemieckiej, Warszawa 1988, s. 223; K. Wysoczyńska, Zofia..., s. 71.

${ }^{48}$ AAN, KHK, Teczka Jadwigi Kuberskiej, sygn. II-K-55, Kwieta Kurkowska, „Relacja o Jadwidze Kuberskiej «Mei»", b.m., b.d., s. 3, mps.

${ }^{49}$ K. Kurkowska-Bondarecka, Kobiece patrole..., s. 98. Podobnie wskazywał Tomasz Strzembosz na podstawie relacji członka KPM Kazimiery Olszewskiej „Miry”; zob. T. Strzembosz, Oddziały szturmowe konspiracyjnej Warszawy 1939-1944, Warszawa 1983, s. 245.

${ }^{50}$ Ewidencja personalna oddziału kobiecego Kedywu Okręgu AK Warszawa, 15 VI 1944 r. [w:] Oddział kobiecy..., s. 42.

${ }^{51}$ H. Michalska et al., Słownik..., s. 171.

${ }^{52}$ A. Marcinkiewicz-Kaczmarczyk, Żeńskie oddziały..., s. 121-122. Według Tomasza Strzembosza „Ludka” była członkiem patrolu Kuberskiej wraz z czterema innymi osobami. Po ich aresztowaniu KPM utraciły kontakt z pozostałymi podkomendnymi „Mei”; zob. T. Strzembosz, Oddziały..., s. 35-36, 37.

${ }^{53}$ W. Königsberg, AK 75..., s. 190; idem, Zabójcze dziewczyny... 
wynajmowanym przez Marię Łozińską-Twarowską „Dobrochnę”, „Nike” oraz Wandę Twarowską „Myszkę”, zorganizowano spotkanie opłatkowe dla członkiń KPM Kedywu Okręgu Warszawskiego AK ${ }^{54}$, którego jedną z uczestniczek była „Mea”. Po jego zakończeniu, pomimo zbliżającej się godziny policyjnej, Kuberska zdecydowała się wracać do swojego domu przy ul. Miodowej 23. W bramie kamienicy została aresztowana przez funkcjonariuszy Gestapo. Następnie w mieszkaniu Niemcy zatrzymali jej siostrę Marię, ojca, Irenę Kalinowską „Ludkę”, ich służącą oraz żołnierzy Oddziału Dyspozycyjnego Kedywu Komendy Głównej Armii Krajowej (KG AK) „Kosa 30”55 - ppor. Jerzego Kleczkowskiego „Jurka” i por. Edwarda Madeja „Felka” 56 .

Maria Łozińska wspominała, że niepokoiła się o „Meę”, bowiem po zakończeniu spotkania opłatkowego opuściła jej mieszkanie tuż przed godziną policyjną. Tego samego wieczoru „Dobrochna” dzwoniła do niej, aby ustalić, czy szczęśliwie wróciła do domu. Telefonu jednak nikt nie odbierał, pomimo wielokrotnych prób. Łozińska wiedziała, że w domu Kuberskich zawsze ktoś jest obecny, a to nasuwało przypuszczenia, że została aresztowana ${ }^{57}$.

W powojennej relacji Zofia Franio „Doktor”, akcentując zaangażowanie konspiracyjne „Mei”, wspominała: „Była w innej 5-ce [patrolu] jedna, która prowadziła magazyn Jadwiga Kuberska ps. «Mea». Pracowała w Opiece Społecznej, zdaje się na Miodowej i gdzieś tam mieszkała. 23 XII 1943 r. przed Bożym Narodzeniem - parę nas - zrobiłyśmy opłatek, na drugi dzień dr Franio telefonuje [do «Mei»] - cisza. A mieszkała z rodzicami. Zrobiła[m] wywiad, gdy [«Mea»] wracała z opłatka wieczorem, w bramie stało Gestapo i cywilny mężczyzna, zapytany czy to ta?- odpowiedział - Ta. Weszli do domu, zastali rodziców czytających gazetki. Wszystkich wzięli. Doniósł krewny kierownika Opieki Społecznej Mieczysław Darmaszek (dostał wyrok Sądu Wojskowego) [...]. Z aresztowaniem «Mei» było dużo kłopotu, bo ona

${ }^{54} \mathrm{~W}$ innej publikacji podnoszono, że wówczas odbywało się tam szkolenie KPM; zob. idem, Mieczysław Darmaszek - konfident zastrzelony przez kobiety, http://www.polska-zbrojna.pl/home/articleshow/22059?t=Mieczyslaw-Darmaszek-konfident-zastrzelony-przez-kobiety\# (dostęp 10 IX 2019). Jednak wobec podania przez tego autora w innych publikacjach iż był to opłatek, wydaje się, że informacja o odbywanym szkoleniu jest błędna.

${ }^{55}$ W maju 1942 r. utworzono Organizację Specjalnych Akcji Bojowych AK o kryptonimie „Osa”, którą w lutym 1943 r. podporządkowano Kedywowi KG AK i 1 III 1943 r. zmieniono kryptonim na „Kosa 30”; T. Strzembosz, Oddziały szturmowe..., s. 57, 208; B. Drzyzga, Zagra-Lin. Oddział sabotażowo-dywersyjny Organizacji Specjalnych Akcji („Osa”, „Kosa”) utworzony do realizacji zamachów na terenie Niemiec, Kraków 2014, s. 37. Na przynależność oddziału do Kedywu KG AK wskazuje również użycie kryptonimu liczbowego „30”, którym oznaczano Kedyw KG AK do sierpnia 1943 r.; zob. M. Ney-Krwawicz, Komenda Główna..., s. 409.

${ }^{56}$ K. Kurkowska-Bondarecka, Kobiece patrole..., s. 97.

${ }^{57}$ AAN, KHK, Teczka Jadwigi Kuberskiej, sygn. II-K-55, Kwieta Kurkowska, „Relacja o Jadwidze Kuberskiej «Mei»", b.m., b.d., s. 3, mps. 
miała magazyny materiałów wybuchowych. W jednym domu, który był uszkodzony w [19]39 r. na poddaszu, przez dziurę w suficie [umieściłyśmy] tam kilka ton [i] magazynowałyśmy. «Mea» była tam zameldowana pod fikcyjnym nazwiskiem. Była obawa, że papiery lewe mogła mieć ze sobą w chwili aresztowania. Trzeba było magazyn zlikwidować. Razem z «Meą» pracowała w tym samym instytucie druga osoba, którą Niemcy też aresztowali i wykończyli. Nie pamiętam nazwiska, bo była dopiero wciągnięta do pracy"58. Tą drugą osobą wskazaną przez Zofię Franio była "Ludka”.

Jednak w meldunku Ireny Hahn „Isi”, Zofii Franio „Doktor” i Antoniny Mijal „Tosi” z lutego 1944 r. wskazywano, że „Mea” została aresztowana 21 grudnia 1943 r. w bramie swojego domu przy ul. Miodowej 23. Następnie kazano jej iść do mieszkania, gdzie zatrzymano także jej rodzinę. „Ludka” została zatrzymana kilka godzin po „Mei” 59 . W sprawozdaniu AK z 15 stycznia 1944 r. informowano, że miało to miejsce 21 grudnia 1943 r. Zatrzymano trzy siostry, ojca ${ }^{60}$, dwóch mężczyzn i praczkę. Ojciec i jedna z sióstr, przebywający na wsi, przyjechali do domu na święta. Zdarzenie nastąpiło tuż po godz. 20.00. Niemcy przyjechali trzema samochodami. Przeprowadzono gruntowną rewizję, która objęła również piwnicę. Zabrano wszystkie zapasy, w tym zgromadzoną w konserwach żywność. Wszystkich osadzono na Pawiaku ${ }^{61}$.

Według Andrzeja Krzysztofa Kunerta i Reginy Domańskiej aresztowanie nastąpiło 22 grudnia 1943 r. Kunert twierdził, że „Felek” i „Jurek” przebywali wówczas przy ul. Miodowej „podczas towarzyskiej wizyty w mieszkaniu znajomej Jadwigi Kuberskiej”62. Z kolei Regina Domańska podnosiła, że zatrzymano wówczas ojca, matkę Janinę, dwie córki Jadwigę i Marię

${ }^{58}$ FGEZ, Teczka Zofii Franio, sygn. 74/WSK, Relacja Zofii Franio, Londyn 15 IX 1971 r., k. 5-6.

${ }^{59}$ AAN, AK, sygn. 203/X-61, Komenda Obszaru Warszawa. Meldunki i informacje o osobach współpracujących z Gestapo, Meldunek Zofii Franio „Doktor”, Ireny Hahn „Isi” i Antoniny Mijal „Tosi”, b.m. 7 II 1944 r., k. 14; Akt oskarżenia Mieczysława Darmaszka z 7 II 1944 r. [w:] Oddziat kobiecy..., s. 36.

${ }^{60} \mathrm{~W}$ literaturze oraz meldunkach AK nie wskazywano pełnych danych ojca „Mei”, tj. Tadeusza Kuberskiego.

${ }^{61} \mathrm{~W}$ meldunku podano błędnie, że aresztowani nosili nazwisko Kowerscy; zob. AAN, AK, sygn. 203/X-100, Komenda Obszaru Warszawa, Rozpracowania, sprawozdania i raporty specjalne nr 2-15/44 dot. Niemców, kolaborantów i komunistów 3 I 1944 r. - 25 VII 1944 r., Raport specjalny 4/44, b.m. 15 I 1944 r., k. 28.

${ }^{62}$ A. K. Kunert, Słownik biograficzny konspiracji warszawskiej 1939-1944, t. 2, Warszawa 1987, s. 83. Nierealne przy tym wydaje się, żeby Kleczkowski i Madej zostali aresztowani u Jadwigi Kuberskiej, zanim według powyższych relacji ona została aresztowana ani żeby ich „towarzyska wizyta” przeciągnęła się do godziny policyjnej, po której zatrzymano „Meę”. 
oraz „Ludkę”. Obie siostry Kuberskie i ich ojca osadzono w areszcie przy al. Szucha ${ }^{63}$.

Inni autorzy jako datę aresztowania wskazywali 23 grudnia $1943 \mathrm{r}$. Leon Wanat, długoletni pisarz więzienia Pawiak, twierdził, że Niemcy zabrali "Ludkę" oraz „Meę" i jej rodzinę. W odniesieniu do „Jurka” i „Felka” podnosił, że zostali zatrzymani 20 grudnia 1943 r. "przypadkowo w lokalu konspiracyjnym przy ul. Miodowej w Warszawie". Nie podał dokładnego numeru domu ani czy miało to miejsce w mieszkaniu "Mei”64. Według Tomasza Strzembosza "Mea” oraz jej podkomendna zostały aresztowane 23 grudnia $1943 \mathrm{r}^{65}$ Autor ten jednak nie podał nazwiska osoby podległej Kuberskiej oraz szczegółów zatrzymania. Taką samą datę zatrzymania „Mei” odnotowała więźniarka Pawiaka Anna Czuperska-Śliwicka. Dodała przy tym, że w jej mieszkaniu - będącym lokalem konspiracyjnym - Gestapo zastało siostry Janinę i Marię Kuberskie, ojca, służącą, a także żołnierzy oddziału „Kosa 30” - „Jurka” i „Felka”. Według niej Maria Kuberska była magistrem farmacji, zaś Janina żołnierzem oddziału dywersyjnego AK ${ }^{66}$. Władysław Bartoszewski, określając datę aresztowania na 23 grudnia 1943 r., precyzował, iż Gestapo zatrzymało: Jadwigę Kuberską, Marię Kuberską wraz z ojcem, kuzynką, Kleczkowskiego i Madeja ${ }^{67}$. Według Stanisława Poznańskiego całą rodzinę Kuberskich oraz "Ludkę" Niemcy zabrali 23 grudnia 1943 r. ${ }^{68}$

Z kolei Zygmunt Śliwicki twierdził, że „Jurek” i „Felek” zostali zatrzymani „przypadkowo [...] w mieszkaniu Kuberskich u przedwojennej znajomej w dniu wigilijnym 1943 r., gdzie znaleziono w czasie rewizji paczki «Biuletynu Informacyjnego» $\mathrm{i}$ «Rzeczypospolitej», które miały być następnego dnia

${ }^{63}$ R. Domańska, Pawiak..., s. 394. W swojej pozycji Domańska powołuje się na opracowanie Emila Kumora oraz meldunek „Kratki” z 30 XII 1943 r. Żadne z tych źródeł nie wskazuje, że wówczas została aresztowana „Ludka”, zaś o natychmiastowym przewiezieniu Kuberskich do siedziby Gestapo przy al. Szucha wspomina tylko Emil Kumor. Co więcej z relacji Kumora wprost wynika, że w mieszkaniu były tylko siostry Kuberskie i ich ojciec. Należy jednak podchodzić do niej z dużą ostrożnością, bowiem przedstawiony opis zdarzenia jest sprzeczny z cytowanym powyżej meldunkiem. Nie zgadza się również z przebiegiem aresztowania „Mei” (powrót Kuberskiej z „opłatka” tuż przed godziną policyjną; jej rozpoznanie i zatrzymanie w bramie domu, a nie w mieszkaniu; zatrzymanie jej obojga rodziców).

${ }^{64}$ L. Wanat, Za murami..., s. 398, 411, 421.

${ }^{65}$ T. Strzembosz, Oddziały..., s. 244.

${ }^{66} \mathrm{~W}$ tym wypadku ewidentnie błędnie wskazano Jadwigę Kuberską jako Janinę; zob. A. Czuperska-Śliwicka, Cztery lata ostrego dyżuru, Warszawa 1989, s. 355.

${ }^{67}$ Autor ten zaznaczył, że oparł się na publikacji Anny Czuperskiej-Śliwickiej; zob. W. Bartoszewski, Warszawski pierścień śmierci 1939-1944. Terror hitlerowski w okupowanej stolicy, Warszawa 2008, s. 367, 370.

${ }^{68}$ S. Poznański, Z otwartych szkatuł, „Stolica” 1964, nr 48 (886), s. 15. 


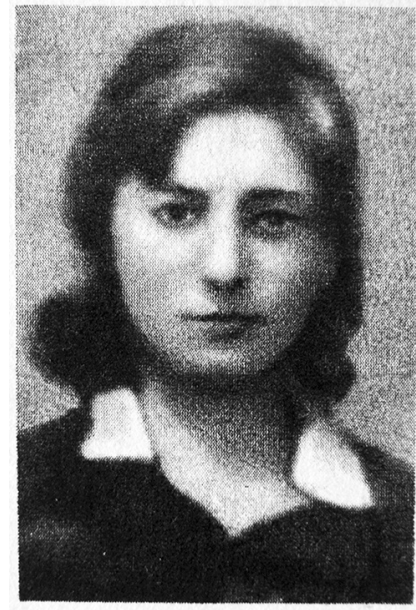

Jadwiga Kuberska „Mea” Źródło: Słownik uczestniczek...

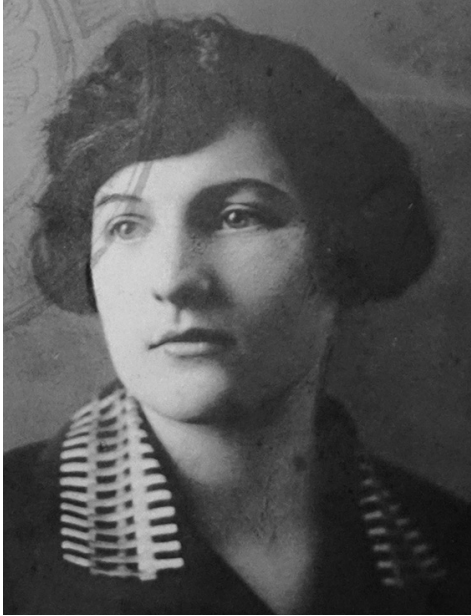

Halina Maria Kuberska

Źródło: Archiwum Uniwersytetu Warszawskiego

rozprowadzone"69. Nie wskazał on żadnych szczegółów dotyczących liczby aresztowanych członków rodziny Kuberskich.

Datę 24 grudnia 1943 r. wskazał Emil Kumor, podnosząc, że tego dnia „Felek” i „Jurek” spotkali przypadkowo na ulicy siostry Kuberskie. Z uwagi na fakt, że nie widzieli się pięć lat skorzystali z zaproszenia na Wigilię do ich mieszkania na ul. Miodowej. Przyszli tam we dwóch bez broni o godz. 19.00. $\mathrm{W}$ domu, oprócz nich, były tylko siostry i ojciec. O północy przybyło Gestapo, które podczas rewizji w kuchni znalazło konspiracyjną prasę, przygotowaną do rozkolportowania w dniu następnym. W domu zatrzymano pięć osób i przewieziono na Pawiak. Trójkę Kuberskich bezpośrednio z więzienia przewieziono do siedziby Gestapo przy al. Szucha. Nikogo nie wydali, biorąc całą winę na siebie ${ }^{70}$.

Sprawę zatrzymania „Mei”, „Jurka” i „Felka” wyjaśniał meldunek z 30 grudnia 1943 r. sporządzony przez komórkę więzienną "Kratkę” z Wydziału Bezpieczeństwa i Kontrwywiadu Oddziału II KG AK: „W dniu 22 grudnia [1943 r.] została aresztowana rodzina Kuberskich /ojciec, matka, 2 córki oraz sublokatorzy «Jurek» i «Feliks»/. Podług przesłanego z terenu ostrzeżenia sypie Darmaszek Mieczysław, pracujący w Opiece Społecznej,

\footnotetext{
${ }^{69}$ Z. Śliwicki, Meldunek..., s. 257. W jednym z meldunków AK informowano, że „Jurek” i „Felek” zostali aresztowani w mieszkaniu znajomej, do której poszli przenocować. Gestapo przybyło aresztować córkę właściciela mieszkania, należącą do NSZ. W mieszkaniu miano znaleźć większą ilość „Szańca”, a obaj żołnierze „Kosy” nie zostali rozpoznani; zob. AAN, AK, sygn. 203/X-100, Komenda Obszaru Warszawa, Rozpracowania, sprawozdania i raporty specjalne nr 2-15/44, dot. Niemców, kolaborantów i komunistów 3 I 1944 r. - 25 VII 1944 r., Raport specjalny 3/44, b.m. 18 I 1944 r., k. 20.
}

${ }^{70}$ E. Kumor, Wycinek $z$ historii jednego życia, Warszawa 1967, s. 226-227. 
szpicel gestapo"71. Wydaje się, że raport ten jest najbardziej szczegółowym źródłem, opisującym zdarzenia, ale i do niego należy odnosić się z ostrożnością.

Nie ulega wątpliwości, że skutkiem działania Mieczysława Darmaszka było aresztowanie m.in. „Mei” i jej rodziny. Z uwagi na pewne rozbieżności w literaturze co do zatrzymanych przez Gestapo członków rodziny Kuberskich konieczne wydaje się przybliżenie ich sylwetek. Według Anny Czuperskiej-Śliwickiej Maria Kuberska była magistrem farmacji ${ }^{72}$. Analiza dostępnych źródeł pozwala przyjąć, że w rzeczywistości była to Halina Maria Kuberska, która urodziła się 17 sierpnia 1907 r. w Brzeźnicy, woj. łódzkie. Była córką aptekarza z Brzeźnicy Tadeusza Kuberskiego i Janiny Pelagii Kuberskiej z domu Jurkowskiej ${ }^{73}$. W latach 1919-1925 uczyła się w Prywatnym Żeńskim Gimnazjum Kazimiery Kochanowskiej w Warszawie i Prywatnym Żeńskim Gimnazjum Heleny Trzcińskiej w Piotrkowie, zaś od września 1925 r. w Prywatnym Żeńskim Gimnazjum PP. Benedyktynek w Przemyślu, gdzie uzyskała świadectwo dojrzałości ${ }^{74}$. Początkowo studiowała na Oddziale Farmacji Wydziału Matematyczno-Przyrodniczego Uniwersytetu w Poznaniu, gdzie ukończyła pierwszy rok studiów ${ }^{75}$. W latach 1930-1933 uczyła się na Wydziale Farmacji Uniwersytetu Warszawskiego, zaś w 1933 r. zdała egzamin i uzyskała stopień magistra farmacji ${ }^{76}$.

Ojciec Jadwigi, Haliny i Marii - Tadeusz Kuberski, ur. 14 października 1879 r., był z wykształcenia farmaceutą. W 1907 r. prowadził aptekę w Brzeźnicy $^{77}$. Był również oficerem zawodowym Wojska Polskiego. W 1923 r.

${ }^{71}$ AAN, Delegatura Rządu na Kraj, sygn. 202/II, t. 17, Wydział Bezpieczeństwa (Międzyorganizacyjne Porozumienie Więzienne), Meldunek „Kratki”, b.m. 30 XII 1943 r., k. 32.

${ }^{72}$ A. Czuperska-Śliwicka, Cztery..., s. 355.

${ }^{73}$ Archiwum Uniwersytetu Warszawskiego (dalej: AUW), Akta osobowe Haliny Marii Kuberskiej, sygn. WFarm 36274, Odpis aktu urodzenia Haliny Marii Kuberskiej, Brzeźnica 21 VIII 1928 r., b.p.; Życiorys Haliny Marii Kuberskiej, Warszawa 8 XI 1930 r., b.p.

${ }^{74}$ AUW, Akta osobowe Haliny Marii Kuberskiej, sygn. WFarm 36274, Świadectwo dojrzałości Haliny Marii Kuberskiej, Przemyśl 13 VI 1927 r., b.p.

${ }^{75}$ Ibidem, Świadectwo nr 43 odejścia z Uniwersytetu Poznańskiego, Poznań 5 XI 1930 r., b.p.

${ }^{76}$ Ibidem, Protokół Komisji Egzaminacyjnej Wydziału Farmacji Uniwersytetu Warszawskiego dot. Haliny Marii Kuberskiej, Warszawa 23 I 1933 r., b.p.; Kalendarz farmaceutyczny na rok 1934, Warszawa 1933, s. 222; Urzędowy spis lekarzy, lekarzy-dentystów, farmaceutów, felczerów, pielęgniarek, położnych, uprawnionych i samodzielnych techników dentystycznych oraz wykazy: aptek, szpitali, ubezpieczalni społecznych, ośrodków zdrowia, przychodni samodzielnych oraz centrali i filii Państwowej Szkoły Higieny, cz. III: Farmaceuci, Warszawa 1939 r., s. 42; H. Michalska et al., Słownik..., s. 223.

77 AUW, Akta osobowe Haliny Marii Kuberskiej, sygn. WFarm 36274, Akta Haliny Marii Kuberskiej, Odpis aktu urodzenia Haliny Marii Kuberskiej, Brzeźnica 21 VIII 1928 r., b.p. Według Anny Rószkiewicz-Litwinowiczowej Tadeusz Kuberski był również właścicielem 


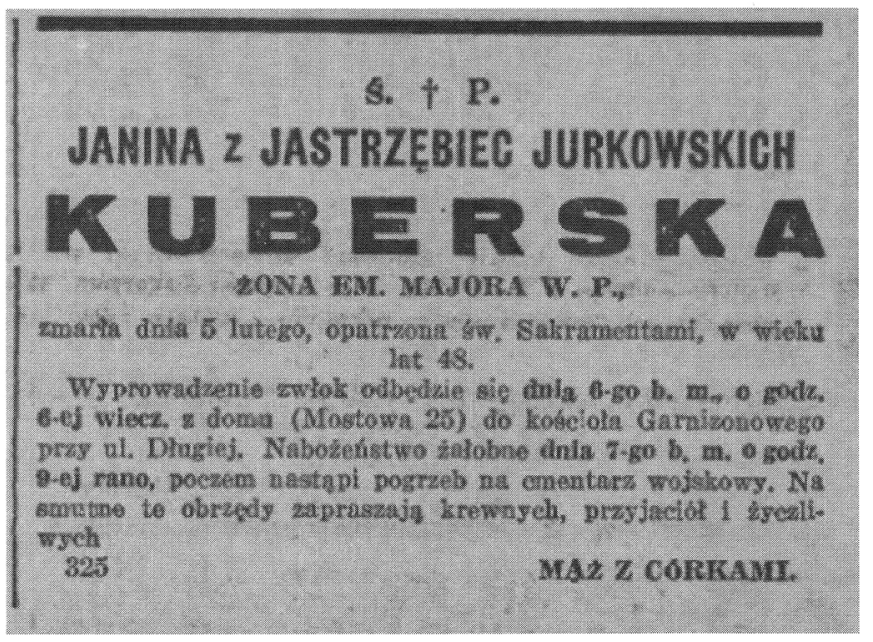

Nekrolog Janiny Kuberskiej z 6 II $1936 \mathrm{r}$. Źródło: zbiory autora

w stopniu kapitana służył w 4 Batalionie Sanitarnym i jako aptekarz pracował w Szpitalu Rejonowym w Piotrkowie Trybunalskim. 15 sierpnia 1924 r. uzyskał awans do stopnia majora i służył w 9 Batalionie Sanitarnym. W 1934 r. został przeniesiony w stan spoczynku i zaliczony do kadry zapasowej 7 Szpitala Okręgowego w Poznaniu ${ }^{78}$. Ta okoliczność oraz fakt, że Halina Kuberska rozpoczęła studia na Uniwersytecie Poznańskim zdaje się wskazywać, że w latach trzydziestych Kuberscy zamieszkiwali w Poznaniu bądź jego okolicy.

Janina Kuberska z domu Jurkowska lub, jak się wskazuje, JastrzębiecJurkowska, ur. prawdopodobnie w 1886 r. ${ }^{79}$ - zm. 5 lutego 1936 r. 7 lutego 1936 r. została pochowana na cmentarzu wojskowym w Warszawie. W jej nekrologu wskazano, że była żoną emerytowanego majora WP ${ }^{80}$. Również Anna Rószkiewicz-Litwinowiczowa twierdziła, że Janina Kuberska zmarła przed wojną ${ }^{81}$.

apteki w Końskich; zob. AAN, KHK, Teczka Jadwigi Kuberskiej, sygn. II-K-55, Anna Litwinowiczowa, Notatka „Siostry Kuberskie”, Warszawa 8 IX 1976 r., s. 1, mps.

${ }^{78}$ Rocznik Oficerski 1923 r., Warszawa 1923, s. 1146; Rocznik Oficerski 1924 r., Warszawa 1924, s. 1068, 1093; Rocznik oficerski rezerw 1934, Warszawa 1934, s. 379, 784.

${ }^{79}$ W 1907 r. Janina Kuberska miała 21 lat; zob. AUW, Akta osobowe Haliny Marii Kuberskiej, sygn. WFarm 36274, Odpis aktu urodzenia Haliny Marii Kuberskiej, Brzeźnica 21 VIII 1928 r., b.p.

${ }^{80}$ Jej grób znajduje się na Cmentarzu Wojskowym w Warszawie kwatera A19, rząd 8, miejsce 4; zob. Nekrolog Janiny Kuberskiej z domu Jastrzębiec Jurkowskiej, „Kurier Warszawski”, 6 II 1936, nr 36; http://www.nekrologi-baza.pl/?page_id=1149\&paged=5670 (dostęp 14 IX 2019); https://www.geni.com/people/Janina-Kuberska/6000000054183018945 (dostęp 14 IX 2019); Zdjęcie grobu Janiny Kuberskiej w zbiorach autora.

${ }^{81}$ AAN, KHK, Teczka Jadwigi Kuberskiej, sygn. II-K-55, Anna Litwinowiczowa, Notatka „Siostry Kuberskie”, Warszawa 8 IX 1976 r., s. 1, mps. 
Najmniej informacji posiadamy o Marii Kuberskiej, urodzonej w 1910 r., siostrze Haliny i Jadwigi. Prawdopodobnie była ona żołnierzem $\mathrm{AK}^{82}$.

W 1930 r. Kuberscy mieszkali w Kolonii „Zdobycz Robotnicza” na warszawskim Żoliborzu ${ }^{83}$. Co najmniej od stycznia 1933 r. do 1940 r. rodzina przebywała przy ul. Mostowej 23/25 m. $4^{84}$. W czasie okupacji Halina Maria Kuberska pracowała w Miejskiej Składnicy Materiałów Aptecznych przy ul. Miodowej $23 \mathrm{w}$ Warszawie ${ }^{85}$. Placówka ta prowadziła działalność w tym okresie, a istniała co najmniej od marca $1939 \mathrm{r}^{86}$

Prawdopodobnie w czasie II wojny światowej rodzina Kuberskich zmieniła miejsce zamieszkania, bowiem od roku 1942 Tadeusz Kuberski występuje jako posiadacz numeru $113122 \mathrm{w}$ spisie abonentów telefonicznych przy ul. Miodowej $23 \mathrm{~m} .25^{87}$. To uprawdopodabnia tezę, że cała rodzina przeniosła się na tę ulicę, gdzie mieszkała przy Miejskiej Składnicy Materiałów

${ }^{82}$ H. Michalska et al., Słownik..., s. 223. W kartotece online Muzeum Więzienia „Pawiak” występują: Maria Kuberska - aresztowana 22 XII 1943 r., stracona 3 II 1944 r.; Jadwiga i Janina Kuberskie - aresztowane 22 XII 1943 r.; zob. Maria Kuberska, http://www.muzeum-niepodleglosci.pl/pawiak/kartoteka-online/?id=17662 (dostęp 25 IX 2019); Jadwiga Kuberska, http://www.muzeum-niepodleglosci.pl/pawiak/kartoteka-online/?id=17660 (dostęp 25 IX 2019); Janina Kuberska, http://www.muzeum-niepodleglosci.pl/pawiak/kartoteka-online/?id=17661 (dostęp 25 IX 2019).

${ }^{83}$ AUW, Akta osobowe Haliny Marii Kuberskiej, sygn. WFarm 36274, Pismo Uniwersytetu Warszawskiego dot. Haliny Marii Kuberskiej, Warszawa 12 XI 1930 r., b.p.

${ }^{84}$ Ibidem, Karta indywidualna dla osób ubiegających się o dyplom, Warszawa 27 I 1933 r., b.p.; Urzędowy spis..., cz. III: Farmaceuci..., s. 42; Spis abonentów warszawskiej sieci telefonów Polskiej Akcyjnej Spółki Telefonicznej rok 1937/38, Warszawa 1937, s. 163. W spisie telefonów Tadeusz Kuberski widnieje jako posiadacz numeru 113122 przy ul. Mostowej 23. Zob. też Spis abonentów warszawskiej sieci telefonów Polskiej Akcyjnej Spółki Telefonicznej rok 1938/39, Warszawa 1938, s. 181; Spis abonentów sieci telefonicznej m. st. Warszawy P.A.S.T. Warszawskiej Sieci Okręgowej P.P.T.T. rok 1939/1940, Warszawa 1938, s. 204.

${ }^{85}$ A. Chodkowska, Ślady warszawskich farmaceutów w czasie II wojny światowej $w$ zbiorach IPN. „Apel poległych”, „Farmacja Polska” 2009, t. 65, nr 9, s. 634, (tu nazwa Składnica Miejska); „Dziennik Zarządu Miejskiego w mieście stołecznym Warszawie”, 24 III 1939, s. 4; Teresa Krassowska [w:] Encyklopedia Medyków Powstania Warszawskiego, https://lekarzepowstania.pl/osoba/teresa-krassowska-ps-joanna/ (dostęp 13 IX 2019). Miejska Składnica Materiałów Aptecznych posiadała telefony o numerach abonenckich: 111515 i 111 533, zaś mieszkanie Kuberskich 113 122, co wskazuje, że mieszkali oni w oddzielnym lokalu; zob. Spis abonentów sieci telefonicznej m. st. Warszawy P.A.S.T...., s. 515.

86 „Dziennik Zarządu Miejskiego w mieście stołecznym Warszawie”, 24 III 1939, s. 4; Spis abonentów sieci telefonicznej m. st. Warszawy P.A.S.T...., s. 515; Teresa Krassowska [w:] Encyklopedia Medyków Powstania Warszawskiego, https://lekarzepowstania.pl/osoba/ teresa-krassowska-ps-joanna/ (dostęp 13 IX 2019).

${ }^{87}$ Urzędowa książka telefoniczna dla Dystryktu Warschau według stanu z dnia 1 VIII 1942 r., Deutsche Post Osten 1942, s. 94; Zawiadomienie o kradzieży w dniu 25 VIII 1943 r. legitymacji oficerskiej na nazwisko Tadeusz Kuberski, „Nowy Kurier Warszawski”, 28-29 VIII 1943, nr 204, s. 6 . 
Aptecznych. Mieszkanie przy składzie mogło być również doskonałą przykrywką dla przenoszenia paczek z materiałami konspiracyjnymi, które z racji częstego przywozu wyposażenia medycznego do składnicy nie zwracały większej uwagi. $Z$ dokumentów wynika również, że trzy siostry Kuberskie i ich ojciec byli zaangażowani w konspirację niepodległościową ${ }^{88}$.

W kartotece Muzeum Więzienia Pawiak występują: Maria Kuberska aresztowana 22 grudnia 1943 r., stracona 3 lutego 1944 r. ${ }^{89}$ oraz Jadwiga i Janina Kuberskie - zatrzymane 22 grudnia 1943 r. ${ }^{90}$ Brak danych dotyczących aresztowania Haliny Kuberskiej i Tadeusza Kuberskiego. W odniesieniu do Jerzego Kleczkowskiego i Edwarda Madeja wpisano dwie różne daty ich zabrania przez Niemców, tj. 22 grudnia 1943 r. i 24 grudnia 1943 r., oraz datę ich egzekucji - 10 lutego 1944 r. ${ }^{91}$ Wydaje się jednak, że w odniesieniu do członków rodziny Kuberskich dane te są nieścisłe.

Analiza podanych wyżej informacji potwierdza, że Janina Kuberska nie mogła zostać schwytana i rozstrzelana, bowiem nie żyła już w chwili wybuchu II wojny światowej. W rzeczywistości, w rodzinie Kuberskich były trzy siostry: Jadwiga, Helena Maria i Maria, które zabrało Gestapo. Wydaje się, że fakt, że dwie z nich miały na imię Maria i używały go na co dzień, spowodował pewne nieścisłości w meldunkach AK i wspomnieniach, przyjmujących, iż Halina i Maria były tą samą osobą, zaś trzecią zatrzymaną kobietą była matka lub kuzynka.

W świetle powyższych danych nadal jednak pozostaje nierozwiązana kwestia daty i miejsca ujęcia Ireny Kalinowskiej „Ludki”. Poza kilkoma relacjami, iż „Ludkę” aresztowano w mieszkaniu „Mei”, brakuje innych informacji na temat czasu i miejsca jej zatrzymania ${ }^{92}$. W meldunku z 7 lutego 1944 r. informowano, że „Ludka” została zabrana przez Niemców kilka godzin później niż „Mea”’3. Nie podano jednak miejsca jej ujęcia, co zdaje

${ }^{88}$ AAN, KHK, Teczka Jadwigi Kuberskiej, sygn. II-K-55, Anna Litwinowiczowa, Notatka „Siostry Kuberskie”, Warszawa 8 IX 1976 r., s. 1, mps; H. Michalska et al., Słownik..., s. 223.

${ }^{89}$ Maria Kuberska, http://www.muzeum-niepodleglosci.pl/pawiak/kartoteka-online/?id=17662 (dostęp 25 IX 2019).

${ }^{90} \mathrm{Jadwiga}$ Kuberska, http://www.muzeum-niepodleglosci.pl/pawiak/kartoteka-online/?id=17660 (dostęp 25 IX 2019); Janina Kuberska, http://www.muzeum-niepodleglosci. pl/pawiak/kartoteka-online/?id=17661 (dostęp 25 IX 2019).

${ }^{91}$ Jerzy Kleczkowski, http://www.muzeum-niepodleglosci.pl/pawiak/kartoteka-online /?id=14200 (dostęp 25 IX 2019); Edward Madej, http://www.muzeum-niepodleglosci.pl/ pawiak/kartoteka-online/?id=14201 (dostęp 25 IX 2019).

${ }^{92}$ AAN, KHK, Teczka Jadwigi Kuberskiej, sygn. II-K-55, Anna Litwinowiczowa, Notatka „Siostry Kuberskie”, Warszawa 8 IX 1976 r., s. 1, mps; K. Kurkowska-Bondarecka, Kobiece patrole..., s. 98; L. Wanat, Za murami..., s. 411.

${ }^{93}$ AAN, AK, sygn. 203/X-61, Komenda Obszaru Warszawa. Meldunki i informacje o osobach współpracujących z Gestapo, Meldunek Zofii Franio „Doktor”, Ireny Hahn „Isi” 
się sugerować, że zatrzymano ją w mieszkaniu „Mei”. Rozbieżność czasowa pomiędzy ich aresztowaniem zdaje się potwierdzać utrzymanie przez Gestapo „kotła” w mieszkaniu Kuberskich. Powyższe dane są jednak sprzeczne z meldunkiem „Kratki” z 30 grudnia 1943 r., w którym nic o „Ludce” nie wspomniano ${ }^{94}$. W meldunku AK, dotyczącym działalności Mieczysława Darmaszka, wskazywano: „[...] Dnia 21.XII. [19]42 r. aresztowana była w mieszkaniu przy ul. Miodowej 23 była urzędniczka Ośrodka J[adwiga] K[uberska] wraz z nią aresztowane były jej 2 siostry, ojciec i 2 nocujących mężczyzn. Jednocześnie aresztowana była przy ul. Zakroczymskiej druga urzędniczka Ośrodka I[rena] K[alinowska] współpracująca z J[adwigą] K[uberską]. Wszystkie te osoby zostały rozstrzelane w lutym 1943 r. [sic! właśc. 1944 r.] Tego samego wieczoru o godz. 11.30 już po aresztowaniu J[adwigi] K[uberskiej] i I[reny] K[alinowskiej] M[ieczysław] Darmaszek przyszedł pijany pod dom nr 24 przy ul. Miodowej. Odprowadzili go żandarmi i kazali dozorcy wpuścić go do domu. Widzieli to pracownicy Ośrodka, którzy tego wieczoru mieli dyżur Opl.[Obrony przeciwlotniczej]. Po aresztowaniu I[reny] K[alinowskiej] zaofiarował rodzinie aresztowanej rzekomą pomoc obiecując interweniować i wykorzystać swoje znajomości Wyłudził od nich ok. 7 tys. zł. Aresztowana została rozstrzelana i jak się później okazało nikt w jej sprawie nie interweniował [...]"95. Z drugiej strony w kartotece Pawiaka odnotowano, że Irena Kalinowska została aresztowana w dniu 22 grudnia 1943 r. ${ }^{96}$

W sytuacji gdyby „Ludka” przyszła do mieszkania Kuberskich, niemożliwe wydaje się, aby została schwytana tego samego dnia co „Mea”. Wyklucza to bowiem czas zatrzymania Kuberskich. Kalinowska, z uwagi na godzinę policyjną, mogła tam przybyć dopiero następnego dnia i wpaść w zasadzkę. Być może jednak, biorąc pod uwagę meldunek wskazujący ul. Zakroczymską jako miejsce ujęcia Kalinowskiej, Gestapo nie urządziło zasadzki w mieszkaniu „Mei”, a aresztowanie obu kobiet było jednoczesne - wykonane w dwóch różnych miejscach Warszawy. Można przypuszczać, że rozbieżność czasowa w meldunku z 7 lutego 1944 r. co do zatrzymania "Ludki” wynika z faktu, że obie kobiety zetknęły się dopiero później. Stąd w „grypsie”, na którym oparto powyższy raport, „Mea” podała inny czas aresztowania Kalinowskiej.

i Antoniny Mijal „Tosi”, b.m. 7 II 1944 r., k. 14; Akt oskarżenia Mieczysława Darmaszka z 7 II 1944 r..., s. 36-37.

${ }^{94}$ AAN, Delegatura Rządu na Kraj, sygn. 202/II, t. 17, Wydział Bezpieczeństwa (Międzyorganizacyjne Porozumienie Więzienne), Meldunek „Kratki”, b.m. 30 XII 1943 r., k. 32.

${ }^{95}$ AAN, AK, sygn. 203/X-100, Komenda Obszaru Warszawa, Rozpracowania, sprawozdania i raporty specjalne nr 2-15/44 dot. Niemców, kolaborantów i komunistów 3 I 1944 r. - 25 VII 1944 r., Raport specjalny 12/44, b.m. 21 III 1944 r., k. 113.

${ }^{96}$ Irena Kalinowska, http://www.muzeum-niepodleglosci.pl/pawiak/kartoteka-online/?id=11640 (dostęp 25 IX 2019). 
Powyższe zdaje się dawać podstawę do stwierdzenia, że na ul. Miodowej 2322 grudnia 1944 r., tuż przed lub tuż po rozpoczęciu godziny policyjnej, Gestapo zatrzymało Tadeusza Kuberskiego - ojca i trzy siostry: Jadwigę, Halinę Marię i Marię Kuberskie oraz sublokatorów ${ }^{97}$ Jerzego Kleczkowskiego i Edwarda Madeja. W tym samym czasie na ul. Zakroczymskiej ujęto "Ludkę".

Prawdopodobnie powodem aresztowania „Mei” i „Ludki” była dekonspiracja w czasie pracy w V Ośrodku Zdrowia i Pomocy Społecznej. Z racji pełnionych funkcji musiały być gotowe na odbiór lub wydanie magazynowanych materiałów pirotechnicznych. To wymagało wykonywania w czasie pracy szeregu rozmów telefonicznych i powodowało konieczność częstego wychodzenia z niej o różnych porach. Mogło to więc zwrócić uwagę konfidenta, który prawdopodobnie obserwował ich pracę, odwiedzając brata w V Ośrodku, a także bywał w domu „Mei”98. Anna Rószkiewicz-Litwinowiczowa, również pracująca w tym samym ośrodku, co Jadwiga Kuberska, wspominała: „W 1944 r., a nawet już pod koniec 1943 r. stale ktoś, głównie kobiety - padał ofiarą aresztowania przez gestapo. Wydawało się nam dziwne to, że według niepisanej umowy wychodziłyśmy o różnych porach - choć powinne byłyśmy pracować od 7 rano do 17-ej po południu, a zawsze na tę, która wychodziła o umówionej godzinie czekało przed wyjściem lub w domu gestapo [...]. W ośrodku widywałam często przystojnego bruneta [...] był to Mieczysław Darmaszek, który przychodził do brata. Byli oni znajomymi Kuberskich [...]. Jak się okazało był on sprawcą wszystkich aresztowań w ośrodku"99.

Prawdopodobnie znalezione w mieszkaniu „Mei” paczki z prasą podziemną skierowały śledztwo Gestapo w kierunku podziemnego kolportażu, nie zaś jej działalności dywersyjnej w ramach KPM. Wydaje się, że Niemcy nie mieli wiedzy o jej pracy konspiracyjnej w oddziale podległym dr Zofii

${ }^{97}$ Relacje i opracowania, uznające, iż żołnierze „Kosy” przyszli z wizytą do „Mei” są sprzeczne z podawanymi w meldunkach AK okolicznościami jej zatrzymania. Źródła te mają charakter opracowań lub wspomnień powojennych, a więc obarczonych błędami, wynikającymi z upływu czasu. Skoro „Mea” została aresztowana sama, zaraz po wejściu do bramy domu, a w tym czasie trwała już godzina policyjna, nie mogła spotkać obu żołnierzy „Kosy” na ulicy, a co za tym idzie - nie mogli jej odwiedzić. Obaj mężczyźni przebywali w czasie nalotu Gestapo w mieszkaniu. W sytuacji gdyby byli gośćmi, winni opuścić mieszkanie przed godziną policyjną. Data ujęcia Kuberskich również wyklucza, aby tego dnia odbywała się u nich Wigilia. Za uznaniem „Jurka” i „Felka” za sublokatorów przemawia przede wszystkim meldunek wywiadu więziennego AK z 30 XII 1943 r. Jest on najbardziej zbliżony czasowo do chwili aresztowania Kuberskich i bazuje na informacjach uzyskanych z Pawiaka.

${ }^{98}$ K. Kurkowska-Bondarecka, Kobiece patrole..., s. 98.

99 AAN, KHK, Teczka Jadwigi Kuberskiej, sygn. II-K-55, Anna Litwinowiczowa, Notatka „Siostry Kuberskie”, Warszawa 8 IX 1976 r., s. 1, mps. 
Franio, bowiem Darmaszek takiej nie zaobserwował. W toku śledztwa Jadwiga Kuberska niczego nie zdradziła. We wniosku o jej odznaczenie podnoszono: „Pomimo bicia nie wskazała żadnej osoby oraz adresu [...]”100. Wydaje się również, że Niemcy nie wiedzieli o działaniach „Jurka” i „Felka” w oddziale „Kosa 30”101. Aresztowani również niczego w czasie śledztwa nie ujawnili. Teza ta wydaje się prawdopodobna $\mathrm{z}$ dwóch powodów. Po pierwsze, według Emila Kumora były prowadzone z Niemcami rozmowy o wykupieniu obu oficerów z Pawiaka ${ }^{102}$. Po drugie, zdaje się na to wskazywać szybka egzekucja aresztowanych na ul. Miodowej po niespełna miesięcznym śledztwie. Wydaje się, że gdyby Gestapo miało informacje o rzeczywistym rodzaju pracy konspiracyjnej „Felka”, „Jurka”, „Ludki” i „Mei”, nie zostaliby oni straceni tak szybko. Niemożliwa byłaby również zgoda Niemców na rozmowy w celu wykupienia żołnierzy „Kosy”. Odnotować również należy, że w tym czasie przesłuchania Gestapo trwały dwa tygodnie. Po tym okresie, w razie ustalenia winy kierowano osobę na rozstrzelanie, $w$ razie braku jej potwierdzenia przekazywano ją na Pawiak. Po czterotygodniowym pobycie w więzieniu ponownie odbywało się ostatnie przesłuchanie w siedzibie Gestapo, po którym - w razie dalszego braku dowodów - taką osobę zwalniano ${ }^{103}$. W jednym z meldunków informowano: „W pierwszej połowie stycznia [1944 r.] odbywały się masowo przesłuchiwania na korytarzach «Pawiaka», zakańczające mniej ważne sprawy. W ten sposób około 300 kobiet jest gotowych do zwolnienia, do obozu lub na karę śmierci" ${ }^{104}$. Służby Kleczkowskiego i Madeja w oddziale bojowym Gestapo nie mogło uznać za sprawę „mniej ważną” i postąpić według wskazanego powyżej trybu. Dlatego jedynym logicznym wytłumaczeniem była niewiedza Niemców o ich konspiracyjnym przydziale.

Pomimo aresztowania „Mea” była w kontakcie z KPM. Już 30 grudnia 1943 r. przesłała gryps, w którym opisała szczegóły swojego zatrzymania i jego sprawcę ${ }^{105}$. Ujęcie Kuberskiej spowodowało konieczność szybkiego

${ }^{100}$ Oddział kobiecy..., s. 11; Wnioski o odznaczenia Krzyżem Walecznych [w:] ibidem, s. 50.

${ }^{101}$ Istnieje jednak meldunek, w którym znajduje się enigmatyczny zapis, iż Niemcy rozszyfrowali przynależność organizacyjną „Jurka”; zob. AAN, AK, sygn. 203/X-100, Komenda Obszaru Warszawa, Rozpracowania, sprawozdania i raporty specjalne nr 2-15/44 dot. Niemców, kolaborantów i komunistów 3 I 1944 r. - 25 VII 1944 r., Raport specjalny 5/44, b.m. 15 I 1944 r., k. 39.

${ }^{102}$ E. Kumor, Wycinek..., s. 225-226.

${ }^{103}$ AAN, AK, sygn. 203/X-100, Komenda Obszaru Warszawa, Rozpracowania, sprawozdania i raporty specjalne nr 2-15/44 dot. Niemców, kolaborantów i komunistów 3 I 1944 r. - 25 VII 1944 r., Raport specjalny 5/44, b.m. 1 II 1944 r., k. 41.

${ }^{104}$ Ibidem, Raport specjalny 6/44, b.m. 8 II 1944 r., k. 53.

${ }^{105}$ AAN, AK, sygn. 203/X-61, Komenda Obszaru Warszawa, Meldunek Zofii Franio „Doktor”, Ireny Hahn „Isi” i Antoniny Mijal „Tosi”, b.m. 7 II 1944 r., k. 14; KHK, Teczka Jadwigi 
opróżnienia wszelkich znanych jej magazynów. Działanie to miało na celu uniknięcie przejęcia przez Niemców zgromadzonych środków pirotechnicznych, w sytuacji gdyby „Mea” nie wytrzymała tortur. W ewakuacji wzięło udział 15 kobiet, które 31 grudnia 1943 r., w ciągu kilku godzin, przeniosły ponad dwie tony materiałów wybuchowych. Jednak pomimo okrutnego śledztwa Jadwiga Kuberska nie zdradziła żadnych tajemnic konspiracyjnych. Po śmierci „Mei” uprzednio opróżniony lokal przy ul. Zakroczymskiej 4 nadal wykorzystywano jako magazyn broni palnej, granatów oraz materiałów minerskich ${ }^{106}$.

W materiałach źródłowych nie ma jakichkolwiek danych o przebiegu śledztwa „Ludki”, ale z powodu braku kolejnych aresztowań należy przyjąć, że również ona nie zdradziła konspiracyjnych tajemnic. „Mea”, „Ludka” oraz Halina i Maria Kuberskie zostały rozstrzelane 3 lutego 1944 r. w egzekucji na terenie getta ${ }^{107}$. „Jurek” i „Felek” zginęli 10 lutego 1944 r. w egzekucji na ul. Barskiej $4^{108}$. Meldunek z 6 lutego 1944 r. informował: „W dniu 3.II [1944 r.] rozstrzelano 147 mężczyzn i 13 kobiet: trzy Kuberskie, Kalusińska, Pipiórska, Milewska, Kalinowska, Gałązka, Lubawska, Popiel, Matusiak Janina, Domaniewska, Berda"109. Władysław Bartoszewski informował, że stracono wówczas Jadwigę Kuberską, Marię Kuberską i Kuberską III ${ }^{110}$. Regina Domańska twierdziła, że rozstrzelano Jadwigę, Janinę i Marię Kuberskie ${ }^{111}$. Analiza publikacji Anny Czuperskiej-Śliwickiej wskazuje, że rozstrzelano siostry Jadwigę i Marię, ich ojca i kuzynkę ${ }^{112}$. Reasumując powyższe okoliczności, należy przyjąć, że 3 lutego 1944 r. stracono trzy siostry Kuberskie, ich ojca Tadeusza i „Ludkę”.

Kuberskiej, sygn. II-K-55, Kwieta Kurkowska, „Relacja o Jadwidze Kuberskiej «Mei»”, b.m., b.d., s. 6, mps; Akt oskarżenia Mieczysława Darmaszka z 7 II 1944 r...., s. 36-37.

106 AAN, KHK, Teczka Jadwigi Kuberskiej, sygn. II-K-55, Kwieta Kurkowska, „Relacja o Jadwidze Kuberskiej «Mei»”, b.m., b.d., s. 6, mps; K. Wysoczyńska, Zofia..., s. 72.

${ }^{107}$ W meldunku Zofia Franio „Doktor” wskazywała, że obie zostały rozstrzelane w styczniu 1944 r.; zob. Ewidencja personalna oddziału kobiecego Kedywu Okregu AK Warszawa, 15 VI 1944 r. [w:] Oddział kobiecy..., s. 42, 43. Wskazywano również, że zostały rozstrzelane na Pawiaku; zob. K. Kurkowska-Bondarecka, Kobiece patrole..., s. 98.

${ }^{108}$ A. Czuperska-Śliwicka, Cztery..., s. 355; W. Bartoszewski, Warszawski..., s. 367, 370; A. Kunicki, Cichy front, Warszawa 2015, s. 67.

${ }^{109}$ AAN, Delegatura Rządu na Kraj, sygn. 202/II, t. 17, Wydział Bezpieczeństwa (Międzyorganizacyjne Porozumienie Więzienne), Meldunek „Kratki”, b.m. 6 II 1944 r., k. 49.

${ }^{110}$ W. Bartoszewski, Warszawski..., s. 367.

${ }^{111}$ R. Domańska, Pawiak..., s. 415. Autorka powołuje się przy tym jednak na cytowany wyżej meldunek „Kratki” z 6 II 1944 r., który poza Jadwigą nie podaje imion straconych Kuberskich.

${ }^{112}$ A. Czuperska-Śliwicka, Cztery..., s. 355. 
Egzekucja z 3 lutego 1944 r. była prawdopodobnie odwetem za to, że żołnierze oddziału „Pegaz” ${ }^{113} 1$ lutego 1944 r. zabili Franza Kutscherę ${ }^{114}$. Jednak publikowane przez Niemców obwieszczenia o egzekucjach nie podawały nazwisk straconych mężczyzn i kobiet, czego przykładem może być takie zawiadomienie z 2 lutego $1944 \mathrm{r}^{115}$

Uzyskana przez KPM wiedza o okolicznościach aresztowania „Mei” i „Ludki” spowodowała podjęcie działań, mających na celu zlikwidowanie Mieczysława Darmaszka. Z uwagi na rozkaz dowódcy Sił Zbrojnych w Kraju, według którego likwidacja obywatela Rzeczypospolitej Polskiej musiała być poprzedzona wyrokiem sądu, jego sprawę należało skierować na drogę sądową ${ }^{116} .7$ lutego 1944 r. Zofia Franio „Doktor”, Irena Hahn „Isia” i Antonina Mijal „Tosia” skierowały do dowódcy Kedywu Okręgu Warszawa AK ppor. Józefa Rybickiego „Andrzeja” zawiadomienie o zadenuncjowaniu przez Mieczysława Darmaszka „Mei” i „Ludki”. Wskazały w nim, że: „Dn[ia] 21 XII [19]43 r. między 20-21 została aresztowana Mea, członkini oddziału Kob[iecego] Kedywu. Tego samego dnia w kilka godzin później aresztowano Ludkę, również członkinię od[działu] Kob[iecego]. Po nawiązaniu stosunków z Paw[iakiem] otrzymano od Mei grypsy, w których podaje ona szczegóły swego aresztowania. Gdy wracała wieczorem do domu w bramie czekało na nią G-[esta]po. Wśród G-[esta]powców zauważyła znajomego M.[ieczysława] D.[armaszka], do którego jeden z G-[esta]powców zwrócił się z zapytaniem: «Czy to ta?» M.[ieczysław] D.[armaszek] odpowiedział twierdząco. Wtedy kazano Mei iść do mieszkania, gdzie aresztowano całą rodzinę i wszystkich domowników (6 osób). Zważywszy, że była to już godz. policyjna M.[ieczysław] D.[armaszek] nie mógł znaleźć się w obcej bramie przypadkowo. M.[ieczysław] D.[armaszek] ma brata B.[ogusława] D.[armaszka],

${ }^{113}$ Oddział do zadań specjalnych Kedywu KG AK został, pod kryptonimem „Agat” („AntyGestapo”), powołany 1 VIII 1943 r. Od 26 XI 1943 r. oddział zmienił kryptonim na „Pegaz” („Przeciw Gestapo”), zaś na przełomie czerwca-lipca 1944 r. otrzymał kryptonim „Parasol”; zob. Archiwum Muzeum Powstania Warszawskiego w Warszawie (dalej: AMPW), sygn. P/7989/14, Pismo mjr. Wacława Janaszka „Bolka” do „81” w sprawie zmiany kryptonimów, b.m. 26 XI 1943 r., b.p.; P. Stachiewicz, „Parasol”. Dzieje oddziału do zadań specjalnych Kierownictwa Dywersji Komendy Głównej Armii Krajowej, Warszawa 1984, s. 62, 138; W. Parzyński, Zabić Franza Kutscherę, Gdańsk 2015, s. 101. Kryptonimem „81” oznaczano Kedyw KG AK od listopada 1943 r.; zob. M. Ney-Krwawicz, Komenda Główna..., s. 411.

${ }_{114}$ Początkowo Niemcy planowali w odwecie za zabicie Kutschery rozstrzelać wszystkich więźniów Pawiaka; zob. AAN, AK, sygn. 203/X-100, Komenda Obszaru Warszawa, Rozpracowania, sprawozdania i raporty specjalne nr 2-15/44 dot. Niemców, kolaborantów i komunistów 3 I 1944 r. - 25 VII 1944 r., Raport specjalny 7/44, b.m. 14 II 1944 r., k. 65.

${ }^{115}$ W. Bartoszewski, Warszawski..., s. 367.

116 AAN, AK, sygn. 203/VIII-1, Kierownictwo Walki Podziemnej 1942-1944, Rozkaz nr 165 gen. Stefana Roweckiego „Grota”, b.m. 6 VII 1943 r., k. 12-13. 
który pracuje w V Ośr.[odku] Zdrowia i którego M.[ieczysław] D.[armaszek] często odwiedza. Z tego tytułu M.[ieczysław] D.[armaszek] zna wszystkie urzędniczki i wszystkich urzędników Ośrodka. Mea przed 1/2 rokiem również pracowała w tym Ośr.[odku], a Ludka pracowała do chwili ostatniej. Z grypsów Mei, w których opisuje ona przebieg śledztwa wynika, że nici do aresztowania szły z Ośr.[odka] i że w ciągu 2 mies.[ięcy] była ona obserwowana. Na drugi dzień po aresztowaniu B.[ogusław] D.[armaszek] opowiadał w biurze szczegóły aresztowania (naturalnie zniekształcone) tłumacząc swe wiadomości tym, że jego brat ma znajomości wśród G-[esta]po [...]. Faktem jest również, że sam M.[ieczysław] D.[armaszek], który na początku okresu łapanek był zabrany na ulicy został tegoż dnia wieczorem zwolniony. Zważywszy powyższe oskarżam p. M.[ieczysława] D.[armaszka], że jest on konfidentem G-[esta]po i jest winnym aresztowania Mei (wraz z domownikami) i Ludki, a możliwe, że również innych urzędników Ośrodka. Według ostatnich wiadomości Mea wraz z rodziną i Ludka już nie żyją"117.

10 lutego 1944 r. „Andrzej” przesłał ww. meldunek „Doktor”, „Isi” i „Tosi”, określając go mianem aktu oskarżenia, do dowództwa Okręgu Warszawskiego AK. Z kolei 29 lutego 1944 r. szef sztabu okręgu mjr Stanisław Weber „Chirurg” w piśmie skierowanym do ppor. Stanisława Robaka „Grabca” podnosił: „Oskarżenie na Darmaszka Mieczysława przesyłam, żądam skierowania oskarżenia do sądu. O ile są braki proszę o ich podanie a zażądam uzupełnienia od p. Andrzeja" ${ }^{118}$. Podporucznik Stanisław Robak "Grabiec” był w tym czasie prokuratorem WSS Okręgu Warszawskiego AK. Zwierzchnikiem sądowo-karnym tego sądu był dowódca Okręgu Warszawskiego AK płk Antoni Chruściel „Madej”/,Nurt”119.

Statut WSS wskazywał w art. 1, że ich właściwości podlegały wszystkie przestępstwa godzące w bezpieczeństwo Sił Zbrojnych w Kraju ${ }^{120}$. 6 lipca 1943 r. dowódca Sił Zbrojnych w Kraju wydał rozkaz w sprawie „Organizacji Kierownictwa Walki Podziemnej”. W pkt. 7 ww. rozkazu określono,

${ }^{117}$ AAN, AK, sygn. 203/X-61, Komenda Obszaru Warszawa. Meldunki i informacje o osobach współpracujących z Gestapo, Meldunek Zofii Franio „Doktor”, Ireny Hahn „Isi” i Antoniny Mijal „Tosi”, b.m. 7 II 1944 r., k. 14; Akt oskarżenia Mieczysława Darmaszka $z 7$ II 1944 r...., s. 36-37.

118 AAN, AK, sygn. 203/X-61, Komenda Obszaru Warszawa. Meldunki i informacje o osobach współpracujących z Gestapo, Adnotacja odręczna ppor. Józefa Rybickiego „Andrzeja”, b.m. 10 II 1944 r., k. 14; Adnotacje odręczne mjr. Stanisława Webera „Chirurga”, b.m. 29 II 1944 r., k. 14a; Adnotacja odręczna Józefa Rybickiego „Andrzeja”, 10 II 1944 r. [w:] Oddział kobiecy..., s. 37; Adnotacje odręczne Stanisława Webera „Chirurga” [w:] ibidem, s. 37.

119 B. Szyprowski, Wojskowy wymiar sprawiedliwości Armii Krajowej w czasie okupacji niemieckiej [w:] Porządek publiczny i bezpieczeństwo w okupacyjnej Warszawie, red. W. Spałek, Warszawa 2018, s. 74.

${ }^{120}$ AAN, AK, sygn. 203/XV-3, Komenda Obszaru Lwów, Statut Wojskowych Sądów Specjalnych, b.m. 27 XI 1941 r., k. 20. 
że konspiracyjny wymiar sprawiedliwości zostanie podzielony na trzy piony: Wojskowe Sądy Specjalne, Cywilne Sądy Specjalne i Komisje Sądzące Walki Podziemnej. Do kompetencji sądów wojskowych miały należeć dwie kategorie spraw o czyny godzące w bezpieczeństwo Sił Zbrojnych w Kraju oraz czyny popełniane przez żołnierzy Sił Zbrojnych w Kraju. Pozostałe sprawy miały rozpatrywać Cywilne Sądy Specjalne, zaś Komisje sprawy o czyny mniejszej wagi, godzące w zasady oporu wobec okupanta. Jednocześnie dowódca przypomniał, że zgładzenie obywatela Rzeczypospolitej Polskiej mogło nastąpić jedynie w wyniku skazującego wyroku sądu. Przewidywano jednak wypadki „koniecznej akcji prewencyjnej”, które miano określić w instrukcji specjalnej ${ }^{121}$. Powyższe zasady zostały powtórzone w pkt. 8 zarządzenia Delegata Rządu RP na Kraj Jana Stanisława Jankowskiego „Klonowskiego"122. W art. 1 statutu Cywilnych Sądów Specjalnych określono, że podlegają im sprawy o przestępstwa dotyczące działania na korzyść okupanta bądź na szkodę państwa polskiego lub narodu polskiego w postaci zdrady, szpiegostwa, prowokacji i prześladowania ludności polskiej. Nie podlegały im sprawy zastrzeżone do właściwości WSS ${ }^{123}$.

Nie ulega wątpliwości, że decyzja o skierowaniu sprawy Mieczysława Darmaszka do WSS, jako jedynie właściwego do jej rozpoznania, była słuszna. Co prawda nie był on członkiem AK, ale w wyniku działania konfidenta aresztowane zostały osoby, będące żołnierzami Armii Krajowej. Jego postępowanie wypełniło więc dyspozycję wskazaną w powołanych powyżej przepisach, tj. godziło w bezpieczeństwo Sił Zbrojnych w Kraju.

Jak wspominała Kwieta Kurkowska-Bondarecka: „Na podstawie grypsu otrzymanego od «Mei» i innych wiadomości pani «Doktor» skierowała odpowiedni wniosek do Kierownictwa Walki Podziemnej. Po dokładnym zbadaniu sprawy Konspiracyjny Sąd Specjalny Okręgu Warszawy wydał wyrok śmierci na Mieczysława Darmaszka"124. Z kolei Anna Rószkiewicz-Litwinowiczowa informowała, że w lutym 1944 r., pełniący w tym czasie obowiązki szefa Wydziału Kontrwywiadu Okręgu Warszawskiego AK, por. Wincenty Kwieciński „Lotny” wysłał do sądu akt oskarżenia przeciwko Mieczysławowi Darmaszkowi ${ }^{125}$. Niestety, autorka nie przedstawiła innych informacji

${ }^{121}$ AAN, AK, sygn. 203/VIII-1, Kierownictwo Walki Podziemnej 1942-1944, Organizacja Kierownictwa Walki Podziemnej, b.m. 6 VII 1943 r., k. 12-13.

${ }^{122}$ Ibidem, Zarządzenie w przedmiocie organizacji Kierownictwa Walki Podziemnej Jana Jankowskiego „Klonowskiego”, b.m. 15 VII 1943 r., k. 14-15.

${ }^{123}$ Ibidem, Statut Sądów Specjalnych, b.m., b.d., k. 28; Postanowienie w sprawie Cywilnych Sądów Specjalnych na terenie Inspektoratu, b.m., b.d., k. 33-34.

${ }^{124}$ K. Kurkowska-Bondarecka, Kobiece patrole..., s. 99.

${ }^{125}$ A. Rószkiewicz-Litwinowiczowa, Trudne decyzje. Kontrwywiad Okręgu Warszawa AK 1943-1944. Więzienie 1949-1954, Warszawa 1991, s. 40. 
precyzujących sąd, do którego „Lotny” miał go skierować, ani sposobu rozpoznania tej sprawy karnej. Nie ulega wątpliwości, że „Lotny” z racji służby w komórce kontrwywiadu AK był upoważniony do występowania z meldunkami do WSS Okręgu Warszawskiego. Niemniej jednak „Lotny” nie był uprawniony do sporządzenia aktu oskarżenia, mógł to bowiem zrobić jedynie prokurator tego sądu, którym był „Grabiec"126. Być może w tym wypadku chodziło o jakiś rodzaj meldunku „Lotnego”, charakteryzujący osobę i działalność Mieczysława Darmaszka. Niemniej jednak są to przypuszczenia, bowiem nie zachowały się w tym zakresie żadne dokumenty.

W „Biuletynie Informacyjnym” nr 21 (228) z 25 maja 1944 r. ukazał się komunikat Kierownictwa Walki Podziemnej (KWP) o treści: „Wyrokiem Sądu Specjalnego Cywilnego Okręgu Warszawy zostali skazani na karę śmierci i utratę praw publicznych i obywatelskich praw honorowych: [...] 2) Darmaszek Mieczysław, syn Aleksandra i Konstancji [...] za współpracę z policją niemiecką jako konfidenci. Wyroki wykonano przez zastrzelenie"127. Z powyższego zdaje się wynikać, że sprawa Darmaszka została rozpoznana przez sąd. Niemniej jednak i tu są pewne wątpliwości. Zdziwienie autora budzi fakt, że Mieczysław Darmaszek został skazany wyrokiem „cywilnego" sądu konspiracyjnego. Być może wpływ na powyższe miały cytowane wyżej doniesienia o wydaniu przez niego Niemcom osób niebędących członkami AK (rodzina Stasiaków, Kwiatkowski, osoba ukrywająca radio, szkolni koledzy) oraz meldunek komórki policyjnej 993P, iż Mieczysław Damaszek miał spowodować „wsypę w V Ośrodku [Zdrowia i Pomocy Społecznej], w wyniku czego były tam w 1943 r. aresztowania"128. Raport nr 105 nie zawierał informacji, wskazujących, aby aresztowani byli żołnierzami AK, a sprawy karne dotyczące czynów na szkodę obywateli polskich podlegały rozpoznaniu przez CSS. Wydaje się przy tym, że był to wyrok wydany ex post już po wykonaniu likwidacji. Wskazywać na to może data

${ }^{126}$ Kontrwywiad Okręgu Warszawskiego przewidywał utworzenie referatu spraw sądowych i dochodzeń, w celu przeprowadzania czynności na zlecenie sądu, opracowania materiału dowodowego i kierowanie go do sądu; zob. AMPW, sygn. P/6454, Schemat organizacyjny Kontrwywiadu Okręgu Warszawskiego AK, b.m. 10 VI 1943 r.; Schemat organizacyjny Kontrwywiadu Okręgu Warszawskiego AK, 10 VI 1943 r. [w:] Okręg Warszawa-Miasto..., s. 238.

127 „Biuletyn Informacyjny”, 25 V 1944, nr 21 (228), s. 8. Podobna informacja została przedstawiona w konspiracyjnej „Agencji Prasowej” i „Rzeczpospolitej Polskiej”; zob. „Agencja Prasowa”, 25 V 1944, nr 21 (214), s. 2. Komunikat KWP opublikowany w „Rzeczpospolitej Polskiej” był datowany na 19 V 1944 r. Podawał również, że Mieczysław Darmaszek miał 27 lat; zob. „Rzeczpospolita Polska”, 28 V 1944, nr 7 (79), s. 5-6. Wcześniej wydane publikacje konspiracyjne, przedstawiając komunikaty KWP o wydanych wyrokach, nie informowały o skazaniu M. Darmaszka, co zdaje się wskazywać, że krótko przed datą publikacji uzyskano wyrok. To również może potwierdzać tezę o wydaniu wyroku skazującego już po wykonaniu likwidacji.

${ }^{128}$ AAN, AK, sygn. 203/III-112, Komenda Główna Oddział II, Raport nr 105 „P24/I”, b.m. 16 V 1944 r., k. 19. 
ukazania się komunikatu KWP. Gdyby bowiem zapadł wyrok nie przesyłano by sprawy Darmaszka do rozstrzygnięcia sądowi wojskowemu, zaś „Nurt” nie wydawałby zgody na likwidację prewencyjną wiedząc o toczącym się uprzednio postępowaniu przed CSS. Możliwe jest również twierdzenie, iż WSS, po likwidacji Darmaszka, nie przeprowadził postępowania, wiedząc, że w sprawie wyrokował CSS, zaś cel w postaci eliminacji agenta i jej późniejszego potwierdzenia wyrokiem sądu został osiągnięty ${ }^{129}$.

Wydaje się jednak, że do uprzedniego wydania wyroku sądu w tej sprawie nie doszło, a zabicie Darmaszka miało charakter likwidacji prewencyjnej. Prawdopodobnie rozmowy członkiń KPM z dowództwem okręgu AK, dotyczące usunięcia konfidenta, prowadzono, zanim jeszcze podjęto działania, w celu wszczęcia procedury sądowej. Trwały one już, zanim ppor. Józef Rybicki „Andrzej” przesłał meldunek o działalności konfidenta. 17 stycznia 1944 r. płk Antoni Chruściel „Nurt” wydał bowiem rozkaz: „Zezw. [alam] na wykonanie likw.[idacji] przez patrol kobiecy [nieczytelne] w wypadku istotnej potrzeby. Jeśli nie jest ta likwidacja pilna skierować doniesienie do mnie dla formalnego załatwienia przez Sąd. Tak czy inaczej sprawa musi przejść przez Sąd, a więc oskarżenie"130. Powyższe pismo zezwalało na likwidację prewencyjną Mieczysława Darmaszka przed formalnym uzyskaniem wyroku sądowego. Działanie takie było zgodne z zasadami przyjętymi w armii podziemnej. W piśmie szefa Służby Sprawiedliwości AK ppłk. Konrada Zielińskiego „Karoli” podnoszono: „Rozkazem z dn.[ia] 11.8.[19]43 $\mathrm{Nr}$ 840/I wyjaśnił Komendant Główny, że w przypadku konieczności natychmiastowej likwidacji osoby godzącej w bezpieczeństwo Sił Zbrojnych w Kraju, każdemu dowódcy przysługują uprawnienia [likwidacyjne], wynikające z regulaminów, jednak o fakcie tym należy drogą służbową zawiadomić właściwego prokuratora WSS, celem oceny przez WSS słuszności postępowania. Decyzję natychmiastowej likwidacji powziąć może każdy dowódca bez względu na szczebel dowodzenia, jeśli konieczność natychmiastowej likwidacji jest wyraźna. Motywy swego zarządzenia winien tenże dowódca podać do wiadomości WSS wraz z doniesieniem karnym przeciwko zlikwidowanemu"131. Zasady takie obowiązywały również wcześniej. W instrukcji

${ }^{129} \mathrm{~W}$ jednym z meldunków ppor. Edmund Odorkiewicz „Liw” informował: „Sprawę Darmaszka poleciłem przyśpieszyć”; zob. AAN, AK, sygn. 203/III-174, Komenda Główna Oddział II, Meldunek ppor. Edmunda Odorkiewicza „Liwa” do mjr. Stanisława Webera „Chirurga”, b.m. 15 III 1944 r., k. 159. Nie wiadomo jednak, czy chodziło o przyśpieszenie sprawy sądowej czy też likwidacji. Wydaje się przy tym, że chodzi o sprawę sądową, ponieważ 15 III 1944 r. M. Darmaszek został zastrzelony.

${ }^{130}$ Biblioteka Uniwersytetu Warszawskiego, Gabinet Rękopisów, Spuścizna Józefa Rybickiego, Teka 18/2, nr inw. 5268, Pismo płk. Antoniego Chruściela „Nurta” do ppor. Józefa Rybickiego „Andrzeja”, b.m. 17 I 1944 r., b.p.

${ }^{131}$ AIPN, MBP, 1558/400, AK. Okręg Kraków. Inspektorat Miechów, Pismo ppłk. Konrada Zielińskiego „Karoli”, b.m. 6 III 1944 r., k. 2. 


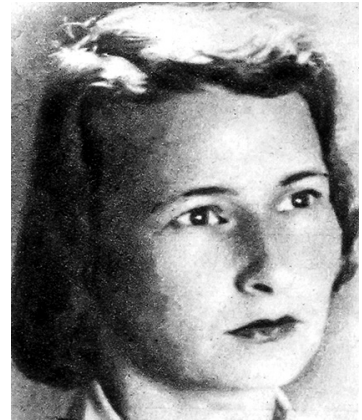

Leta Ostrowska „Justyna” Źródło: zdjęcie udostępnione autorowi przez Wojciecha Königsberga, w zbiorach autora

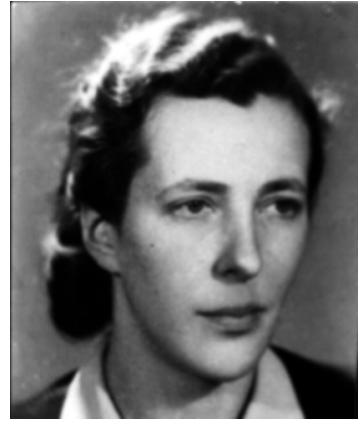

Wanda Kinstler „Bogumiła” Źródło: AAN, KHK, Teczka

Wandy Kinstler, sygn.

II-K-13

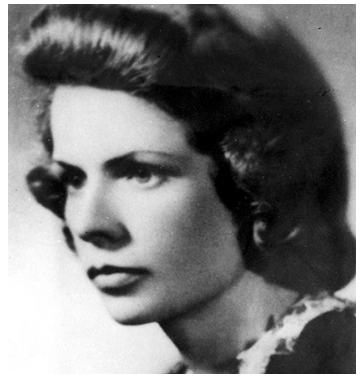

Irena Bredel „Alina” Źródło: zdjęcie udostępnione autorowi przez Wojciecha Königsberga, w zbiorach autora

z 6 lutego 1943 r. szef sztabu Obszaru Warszawskiego AK ppłk Zygmunt Dobrowolski „Mostowicz” podnosił, że każdy komendant obwodu miał nie tylko prawo, ale i obowiązek w razie nagłego, poważnego niebezpieczeństwa grożącego organizacji lub jej członkom, zarządzić na własną odpowiedzialność likwidację sprawcy. Było to dopuszczalne w sytuacji, gdyby skierowanie sprawy na drogę sądową, a w ten sposób odłożenie w czasie likwidacji, mogło spowodować stan groźny dla organizacji. O jej wykonaniu należało niezwłocznie zawiadomić prokuratora WSS. Kopia powyższego rozkazu została przekazana do wiadomości Okręgu Warszawskiego AK, dlatego procedura ta była znana płk. Antoniemu Chruścielowi ${ }^{132}$.

Również supozycja Anny Rószkiewicz-Litwinowiczowej, iż Mieczysław Darmaszek został zlikwidowany „przed wyrokiem w drodze zapobiegawczej”, zdaje się potwierdzać tezę o braku wydania formalnego orzeczenia WSS lub CSS w tym zakresie ${ }^{133}$.

Można przypuszczać, że z chwilą otrzymania zgody „Nurta” na likwidację prewencyjną kobiety z KPM podjęły działania rozpoznawcze wobec konfidenta. Regułą bowiem było, że nawet po wstępnym ustaleniu danych osoby, która miała zostać zlikwidowana, członkowie grupy wykonawczej przeprowadzali szereg czynności, mających na celu ustalenie jej wyglądu, ubioru, miejsca zamieszkania oraz sposobu i tras poruszania się po mieście. Powyższe miało duże znaczenie, bowiem minimalizowało możliwość pomyłki co do podmiotu w czasie likwidacji. Nadto ustalenie tras poruszania się konfidenta

${ }^{132}$ AMPW, sygn. P/6456, Rozkaz ppłk. Zygmunta Dobrowolskiego „Mostowicza”, b.m. 6 II 1943 r., k. 5; Rozkaz Zygmunta Dobrowolskiego „Mostowicza”, 6 II 1943 r. [w:] Okręg warszawski..., s. 18.

${ }^{133}$ A. Rószkiewicz-Litwinowiczowa, Trudne decyzje..., s. 40. 
i rozkład jego codziennych zajęć dawał możliwość takiego wyboru miejsca akcji, aby ewentualne zagrożenia dla wykonawców ze strony okupanta było jak najmniejsze i dawało szanse na ewakuację bez zbędnych strat. Warszawiacy w 1944 r. na odgłos strzałów z reguły reagowali ucieczką z zagrożonego terenu ${ }^{134}$. $Z$ tego powodu najczęściej akcje likwidacyjne przeprowadzano na ulicy, gdzie panika ludności i wmieszanie się w tłum dawały wykonawcom duże szanse uniknięcia zatrzymania przez Niemców po ich realizacji.

Na odprawie KPM przy ul. Wilczej 69 do wykonania zadania zgłosiły się Irena Bredel „Alina” i Letycja Ostrowska „Justyna”. Rozpoczęto działania rozpoznawcze wobec agenta, w tym obserwowano go na ul. Miodowej, bowiem w rozmowach z urzędnikami V Ośrodka Zdrowia uzyskano wiedzę, iż odwiedza brata pracującego w tym ośrodku. W jego obserwacji brały udział m.in. Irena Grabowska „Hanka”, Kwieta Kurkowska „Kwietka” i Michalina Petrykowska „Micia”"135. W działania likwidacyjne Darmaszka została zaangażowana również Alicja Pniewska „Alka” z patrolu Ireny Bredel „Aliny”. Tak to wspominała: „Irena przyszła do mnie i mi powiedziała, że z oddziału minerskiego «Mika» (czy jakoś tak się nazywała) [właśc. «Mea»] została zaaresztowana i że wiedzą, kto ją wydał. Okazało się, że to był folksdojcz ${ }^{136}$. Powiedziała mi Irena, że ona nie wytrzyma dłużej niż parę godzin tortur i że musimy usunąć wszystko z tego miejsca, gdzie ona pracowała i gdzie mogła mieć jakieś rzeczy dyskryminujące [...]. Potem Irena do mnie przyszła i mówi: «Słuchaj, on chodzi po Miodowej i będzie zamach na Miodowej. Potrzebujemy lokalu, więc czy można w twoim mieszkaniu się ulokować i polować na niego?». Powiedziałam: «Naturalnie» [...]. [W dniu likwidacji] przyszła Irena jeszcze z dwiema dziewczynami, których zupełnie nie znałam. Irena była uzbrojona, one były na obstawie. Mnie przed zamachem kazali iść do biura [...], żebym miała alibi. One zrobiły zamach, potem przybiegły [do domu]"137.

${ }^{134}$ Przykładowo można podać tego typu reakcje ludzi w czasie akcji Grup Szturmowych 26 III 1943 r. pod Arsenałem. Stanisław Jastrzębski „Kopeć” wspominał: „Ulica opustoszała z chwilą pierwszych strzałów, więc jak na dłoni widać wszystkich uczestników [akcji]”; zob. S. Jastrzębski, Zaczęło się pod Arsenałem, Warszawa 2017, s. 82. Podobną sytuację zanotował Witold Bartnicki „Kadłubek”: „Wtem rozlega się gwizd, potem strzał, zaraz potem drugi i trzeci. Ostra i bardzo długa seria z peemu [pistoletu maszynowego]. Przechodnie zrywają się do ucieczki, po chwili do placu Teatralnego pędzi szereg osób, przed siebie, na ślepo [...]. Za chwilę dopiero zdałem sobie sprawę, że zwracam na siebie uwagę niezwykłością sytuacji - kieruję się pod prąd uciekinierom. Ulica pustoszeje”; W. Bartnicki, Samochód marki „Renault” [w:] S. Broniewski, Pod Arsenałem, Warszawa 1957, s. 82.

${ }^{135}$ K. Kurkowska-Bondarecka, Kobiece patrole..., s. 99.

${ }^{136}$ Brak potwierdzenia tej informacji.

${ }^{137}$ Rozmowa Małgorzaty Rafalskiej-Dubek z Alicją Pniewska-Sieciechowicz, 9 VII 2012 r., https://www.1944.pl/archiwum-historii-mowionej/alicja-pniewska-sieciechowicz,2912.html (dostęp 12 IX 2019). 
Jak się wydaje, powodem wybrania tej ulicy jako miejsca akcji na Darmaszka był prawdopodobnie fakt, że nie zdołano ustalić jego miejsca zamieszkania, zaś po kontakcie z urzędnikami V Ośrodka Zdrowia i Pomocy Społecznej dowiedziano się, iż odwiedza pracującego tam brata ${ }^{138}$.

Przebieg likwidacji opisywała Kwieta Kurkowska: „Po rozpoznaniu wizyt Darmaszka we wspomnianym Ośrodku Zdrowia zapadła decyzja, że wyrok zostanie wykonany na Miodowej - na tej samej ulicy, na której dokonał on zdrady. W mieszkaniu «Alki» - Alicji Pniewskiej przy ul. Podwale zorganizowano dyżur przy telefonie, przez który pracownicy Ośrodka Zdrowia mieli dać znać o przyjściu Darmaszka do brata (w przeddzień był on w Ośrodku i miał przyjść tam następnego dnia). 8.3.1944 r. ${ }^{139}$ przy Ośrodku Zdrowia i Opieki Społecznej na ul. Miodowej 24 czekały na niego z bronią "Alina» $\mathrm{i}$ «Justyna», natomiast w obstawie były [Wanda Kinstler] «Bogumiła», [Wanda Maciejowska] «Iza», [Irena Grabowska] «Hanka» i ja, trzy ostatnie jako obstawa bez broni. Zgodnie z oczekiwaniem Mieczysław Darmaszek przybył do Ośrodka, gdzie zabawił niedługo. Potem wyszedł i udał się [ul.] Miodową w kierunku [ul.] Kapitulnej. Po drodze wstąpił do fryzjera. My czekałyśmy na ulicy. Kiedy Darmaszek wyszedł od fryzjera nieopodal ul. Kapitulnej, «Alina» $\mathrm{i}$ «Justyna» oddały dwa strzały i konfident padł martwy. W tym czasie nadjechała [ul.] Miodową od Krakowskiego Przedmieścia ciężarówka wioząca Niemców. Jeden z nich wyskoczył z samochodu i zaczął strzelać z karabinu. "Alina» i «Justyna» wycofały się ul. Kapitulną do Podwala. Na nie skierował ogień Niemiec z ciężarówki. Kule jednak nie dosięgły żadnej z nich. Ja z «Izą» $\mathrm{i}$ «Hanką» wycofałyśmy się ul. Miodową do Długiej i dalej do Podwala"140.

Zofia Franio po wojnie opisywała: „Saperki zdecydowały, że to one wykonają wyrok. Podjęły się «Justyna» Ostrowska Leta i Bredel Irena ps. «Alina». Wyrok był bardzo trudny do wykonania, nie wiadomo gdzie mieszkał, itd. Pokazywał się w miejscu pracy Opieki i tam go zaobserwowały. 3 - obstawa. W biały dzień zastrzeliły go na ul. Miodowej, gdy wychodził od fryzjera (bez

${ }^{138}$ K. Kurkowska-Bondarecka, Kobiece patrole..., s. 99.

139 Błędna data, likwidacji dokonano bowiem 15 III $1944 \mathrm{r}$.

${ }^{140}$ K. Kurkowska-Bondarecka, Kobiece patrole..., s. 99. W innym miejscu autorka wskazywała, że w czasie akcji stała koło fryzjera na ul. Miodowej tuż przed ul. Kapucyńską. Po zastrzeleniu Darmaszka wycofała się ul. Kapucyńską do Podwala „już w chwili, gdy Niemcy jadący autem zatrzymali się przy zabitym i zaczęli strzelać”; zob. AAN, KHK, Teczka Kwiety Kurkowskiej, sygn. II-B-59, Kwieta Kurkowska-Bondarecka, Relacja własna, Warszawa 11 V 1974 r., s. 2, mps. Wydaje się, że w relacji pomylono nazwę ulicy. Winna być to ul. Kapitulna, a nie Kapucyńska. 
strat własnych). Obserwacja i poszukiwania trwały b[ardzo] długo. Wyrok wykonały w początkach 1944 r." ${ }^{141}$.

W meldunku, obejmującym zestawienie wyroków zleconych Kedywowi „Kolegium”, pod poz. 89 ujęto Mieczysława Darmaszka z adnotacją: „Wyrok wykonano przez zastrzelenie w dn. 15 III [19]44 o godz. 15.10 na rogu ul. Kapitulnej i Miodowej przez oddział kobiecy Kedywu (Alina, Justyna)"142.

Analizując relację Kwiety Kurkowskiej-Bondareckiej, należy jednak poczynić pewne uwagi, które nakazują ocenić ją ostrożnie. Dotyczą one obstawy wykonawczyń oraz sposobu opuszczenia przez nie miejsca likwidacji. $\mathrm{Z}$ reguły w czasie takiej akcji ubezpieczenie - tzw. obstawa wykonawców - była konieczna, w celu ich ochrony przed działaniem nieprzyjaciela, który chciałby im przeszkodzić $\mathrm{w}$ wykonaniu zadania. W związku $\mathrm{z}$ tym niezbędne było jej uzbrojenie w broń palną, ponieważ bez niej działania obstawy nie były w stanie spełnić swojej funkcji. Liczba wchodzących w nią osób była uzależniona od miejsca wykonania akcji. Gdy na wybranym terenie można było spodziewać się większej liczby uzbrojonego nieprzyjaciela, planując ją należało odpowiednio zwiększyć liczbę wchodzących w obstawę osób oraz należycie je uzbroić. $Z$ drugiej strony zdarzały się sytuacje przeprowadzania likwidacji, gdy egzekutorzy w ogóle nie mieli ubezpieczenia, ponieważ z uwagi na miejsce działania nie była ona potrzebna. Przykładowo Tadeusz Towarnicki „Naprawa” i Leszek Kowalewski „Twardy” z oddziału 993/W początkowo w ogóle nie byli ochraniani w czasie wykonywanych wyroków, np. podczas akcji na Edwarda Golę i Edwarda Metzgera ${ }^{143}$. Można również przywołać działania likwidacyjne Kedywu krakowskiego czy egzekutywy wileńskiej ${ }^{144}$. Niemniej jednak gdy obstawa była wyznaczana, musiała odegrać swoją rolę, a tego nie dało się zrobić, będąc nieuzbrojonym. Dlatego wydaje się, że wskazane przez „Kwietkę” nieuzbrojone członkinie obstawy były w rzeczywistości obserwatorami, tym bardziej że nie zareagowały na strzały oddane przez Niemca w kierunku „Justyny” i „Aliny”. Kolejna kwestia wiąże się z topografią Warszawy. Numer 24 przy ul. Miodowej, gdzie był V Ośrodek Zdrowia i Pomocy Społecznej, znajduje się praktycznie

${ }^{141}$ FGEZ, Teczka Zofii Franio, sygn. 74/WSK, Relacja Zofii Franio, Londyn 15 IX 1971 r., k. 5 .

${ }^{142}$ H. Rybicka, Kedyw Okręgu Warszawskiego..., s. 129.

${ }^{143}$ B. Szyprowski, Sąd Kapturowy przy Komendzie Głównej Związku Walki Zbrojnej w Warszawie (sierpień 1940 r. - listopad 1941 r.). Podziemie w walce ze zdrajcami Rzeczypospolitej, Warszawa 2016, s. 237.

${ }^{144}$ Likwidację Michała Pankowa 12 X 1943 r. w Krakowie przeprowadzili Ryszard Nuszkiewicz „Powolny” i Henryk Januszkiewicz „Spokojny”; zob. R. Nuszkiewicz, Uparci, Warszawa 1983, s. 172-173. W listopadzie 1942 r. Sergiusz Kościałkowski „Lech” i Wacław Zalewski „Biały” dokonali nieudanej próby likwidacji Danuty Wyleżyńskiej; zob. T. Balbus, „Fakir” Sergiusz Kościałkowski. Życie i wojna na Wileńszczyźnie, t. 1, Warszawa 2018, s. 762. 
na skrzyżowaniu z ul. Długą. Z tego miejsca odległość do ul. Kapitulnej wynosi ok. 150-200 m. Skoro Darmaszek wszedł do fryzjera koło ul. Kapitulnej, zaś według „Kwietki” obstawa i wykonawczynie czekały na niego na ulicy, to niezrozumiała jest ucieczka obstawy w kierunku ul. Długiej. Bardziej prawdopodobne jest to, że kobiety, będące „w obstawie”, znajdowały się cały czas w okolicy V Ośrodka Zdrowia, tj. tuż przy skrzyżowaniu z ul. Długą. To mogłoby tłumaczyć ich drogę odwrotu. Z kolei według relacji Alicji Pniewskiej w dniu likwidacji przyszły do jej domu jedynie trzy kobiety, z których tylko Irena Bredel była uzbrojona ${ }^{145}$. To przeczy informacji, aby w akcji uczestniczyło w sumie sześć osób. Udziałowi w niej większej liczby żołnierzy AK przeczy również cytowany powyżej meldunek, który wskazuje, że przeprowadziły ją tylko dwie osoby. Kwieta Kurkowska-Bondarecka nie wyjaśniła również, co tuż po akcji stało się z „Bogumiłą”. Nie wymieniła jej jako jednej z uczestniczek, z którymi się wycofała. To może wskazywać, że „Bogumiła” była tuż przy wykonawczyniach i jako obstawa wraz z nimi wycofała się ul. Kapitulną ${ }^{146}$. Na koniec można dodać, że w czasie rozmowy na temat swojej działalności w konspiracji i w powstaniu Kwieta Kurkowska-Bondarecka, opisując szereg działań które podejmowała, w ogóle nie wspomniała o likwidacji Darmaszka ${ }^{147}$. Z logicznego punktu widzenia nie jest to zrozumiałe, tym bardziej że była to jedyna akcja likwidacyjna wykonana przez KPM, zaś zastrzelenie człowieka z bliskiej odległości musiałoby zapaść jej w pamięć. Powyższe okoliczności zdają się wskazywać, że do jej relacji należy podchodzić $\mathrm{z}$ dużą ostrożnością. Analiza poakcyjnych meldunków AK oraz wspomnień Alicji Pniewskiej w korelacji z opisem Kwiety Kurkowskiej-Bondareckiej zdaje się wskazywać, że w likwidacji Mieczysława Darmaszka w rzeczywistości wzięły udział „Alina” i „Justyna”, zaś ewentualnie ich ubezpieczeniem była „Bogumiła”. Pozostałe osoby wymienione przez „Kwietkę” prawdopodobnie były jedynie obserwatorkami zdarzenia, ale nie brały w nim udziału.

Rozkazem nr 35 z 1 października 1944 r. komendanta Okręgu Warszawskiego AK gen. Antoniego Chruściela „Montera” Jadwiga Kuberska została pośmiertnie odznaczona Krzyżem Walecznych. Jak wskazano we wniosku odznaczeniowym, zadania konspiracyjne wykonywała z pełnym poświęceniem, była zawsze gotowa do podjęcia i wykonania najcięższych

${ }^{145}$ Jak się wydaje, były to „Alina”, „Justyna” i „Bogumiła”.

${ }^{146} \mathrm{~W}$ biogramie Wandy Kinstler, opracowanym przez Kwietę Kurkowską-Bondarecką, podniesiono, że „Bogumiła” była „obstawą z bronią bezpośrednich wykonawczyń”; zob. AAN, KHK, Teczka Wandy Kinstler, sygn. II-K-13, Kwieta Kurkowska-Bondarecka, „Bogumiła" - Wanda Kinstler, b.m. 31 III 1990 r., s. 55.

${ }^{147}$ Rozmowa Pauliny Jędrzejczak z Kwietą Kurkowską-Bondarecką, 8 XII 2010 r. i 14 XII 2010 r., https://www.1944.pl/archiwum-historii-mowionej/kwieta-kurkowska-bondarecka,2336.html (dostęp 12 IX 2019). 
i najniebezpieczniejszych poleceń, a po aresztowaniu, pomimo tortur nie wydała żadnej osoby ani adresu konspiracyjnego ${ }^{148}$.

Analiza dostępnych materiałów archiwalnych zdaje się wskazywać, że Mieczysław Darmaszek był niebezpiecznym agentem Gestapo, a jego działania doprowadziły do szeregu aresztowań żołnierzy AK, jak i osób niezwiązanych z konspiracją. Jednak dopiero wydanie w ręce niemieckie „Mei” i „Ludki” doprowadziło do podjęcia decyzji o likwidacji prewencyjnej. Akcję wykonały dwie kobiety należące do oddziału AK, w którym służyła Jadwiga Kuberska. Były najprawdopodobniej osłaniane jedynie przez Wandę Kinstler „Bogumiłę”. Pozostałe członkinie KPM były tylko obserwatorkami. Jak się wydaje, był to w historii konspiracji niepodległościowej jedyny wypadek, gdy akcję likwidacyjną, i to skuteczną, przeprowadziły kobiety - żołnierze AK. Wydanie wyroku post factum było zgodne z ówczesnymi przepisami, dotyczącymi sądownictwa w konspiracji. Wobec braku dokumentów sądowych nierozstrzygnięta pozostaje kwestia przyczyn, które spowodowały, że wyrok śmierci na Mieczysława Darmaszka wydał sąd podległy Delegaturze Rządu na Kraj, a nie właściwy WSS. Nie ulega jednak wątpliwości, w świetle przytoczonych meldunków o działalności Mieczysława Darmaszka, że decyzja płk. Antoniego Chruściela o likwidacji była ze wszech miar konieczna i uzasadniona oraz miała na celu ochronę organizacji przed działaniem godzącym bezpośrednio w Siły Zbrojne w Kraju.

\section{Bibliografia}

\section{Archiwalia}

Archiwum Akt Nowych w Warszawie

Armia Krajowa

Delegatura Rządu na Kraj

Komisja Historii Kobiet w walce o Niepodległość

Archiwum Instytutu Pamięci Narodowej w Warszawie

Ministerstwo Bezpieczeństwa Publicznego w Warszawie [1944] 1945-1954

Stołeczny Urząd Spraw Wewnętrznych w Warszawie [1944] 1983-1990

Archiwum Muzeum Powstania Warszawskiego

Archiwum Uniwersytetu Warszawskiego

Akta Haliny Marii Kuberskiej

Biblioteka Uniwersytetu Warszawskiego, Gabinet Rękopisów

Spuścizna Józefa Rybickiego

Fundacja Generał Elżbiety Zawadzkiej w Toruniu

Teczka Ireny Bredel

Teczka Zofii Franio

${ }^{148}$ Oddział kobiecy..., s. 18; Wnioski o odznaczenia Krzyżem Walecznych..., s. 50. 


\section{Publikacje}

Balbus T., „Fakir” Sergiusz Kościałkowski. Życie i wojna na Wileńszczyźnie, t. 1, Warszawa 2018.

Bartnicki W., Samochód marki „Renault” [w:] S. Broniewski, Pod Arsenałem, Warszawa 1957.

Bartoszewski W., Warszawski pierścień śmierci 1939-1944. Terror hitlerowski w okupowanej stolicy, Warszawa 2008.

Broniewski S., Pod Arsenałem, Warszawa 1957.

Bułhak W., Kunert A.K., Kontrwywiad podziemnej Warszawy. Struktura, zadania i obsada personalna kontrwywiadu Komendy Głównej, Obszaru Warszawa i Okregu Warszawa ZWZ-AK w latach 1939-1944 [w:] Wywiad i kontrwywiad Armii Krajowej, red. W. Bułhak, Warszawa 2008.

Chodkowska A., Ślady warszawskich farmaceutów w czasie II wojny światowej w zbiorach IPN. „Apel polegtych”, „Farmacja Polska” 2009, t. 65, nr 9.

Czuperska-Śliwicka A., Cztery lata ostrego dyżuru, Warszawa 1989.

Domańska R., Pawiak więzienie gestapo. Kronika 1939-1944, Warszawa 1978.

Drzyzga B., Zagra-Lin. Oddział sabotażowo-dywersyjny Organizacji Specjalnych Akcji („Osa”, „Kosa”) utworzony do realizacji zamachów na terenie Niemiec, Kraków 2014.

Engelking B., Szanowny Panie Gestapo. Donosy do władz niemieckich w Warszawie i okolicach w latach 1940-1941, Warszawa 2012.

Jastrzębski S., Zaczęło się pod Arsenałem, Warszawa 2017.

Kalendarz farmaceutyczny na rok 1934, Warszawa 1933.

Kedyw Okregu Warszawskiego Armii Krajowej. Dokumenty - rok 1943, oprac. H. Rybicka, Warszawa 2006.

Kedyw Okregu Warszawskiego Armii Krajowej. Dokumenty - rok 1944, oprac. H. Rybicka, Warszawa 2009.

Ksiązka informacyjno-adresowa "Cała Warszawa”, Warszawa 1930.

Königsberg W., AK 75. Brawurowe akcje Armii Krajowej, Kraków 2017.

Księgi zgonów z Auschwitz. Fragmenty. Indeks nazwisk, cz. 3, Monachium - Paryż 1995.

Kulesza J., Gartuch. Opowieść o 7. putku piechoty AK w konspiracji i Powstaniu Warszawskim, Warszawa 2014.

Kumor E., Wycinek z historii jednego życia, Warszawa 1967.

Kunert A.K., Słownik biograficzny konspiracji warszawskiej 1939-1944, t. 2, Warszawa 1987.

Kunicki A., Cichy front, Warszawa 2015.

Kurkowska-Bondarecka K., Kobiece patrole minerskie Kedywu Okręgu Warszawskiego ZWZ-AK, „Wojskowy Przegląd Historyczny” 1991, nr 3/4 (137/138).

Marcinkiewicz-Karczmarczyk A., Żeńskie oddziały sabotażowo-dywersyjne $w$ strukturach armii podziemnej w latach 1940-1944 na podstawie relacji i wspomnień ich członkiń, „Pamięć i Sprawiedliwość” 2015, nr 2 (26).

Michalska H., Stopień M., Tazbir-Tomaszewska B., Turkowska W., Zastocka W., Słownik uczestniczek walki o niepodległość Polski 1939-1945. Poległe i zmarłe w okresie okupacji niemieckiej, Warszawa 1988. 
Ney-Krwawicz M., Komenda Główna Armii Krajowej 1939-1945, Warszawa 1990. Nuszkiewicz R., Uparci, Warszawa 1983.

Oddział kobiecy warszawskiego Kedywu. Dokumenty z lat 1943-1945, oprac. H. Rybicka, Warszawa 2002.

Oddziały i żołnierze NSZ w Powstaniu Warszawskim, red. I. Sawicka, Warszawa 1998.

Okręg Warszawa-Miasto ZWZ i Okręg Warszawski ZWZ-AK. Dokumenty 1940-1943. Archiwum „Drapacza” ze skrzynki „Ali”, t. II, oprac. M. Olczak, M. Strok, Warszawa 2018.

Parzyński W., Zabić Franza Kutscherę, Gdańsk 2015.

S. Poznański, Z otwartych szkatuł, „Stolica” 1964, nr 48 (886).

Rocznik Oficerski 1923 r., Warszawa 1923.

Rocznik Oficerski 1924 r., Warszawa 1924.

Rocznik oficerski rezerw 1934, Warszawa 1934.

Rószkiewicz-Litwinowiczowa A., Trudne decyzje. Kontrwywiad Okręu Warszawa AK 1943-1944. Więzienie 1949-1954, Warszawa 1991.

Spis abonentów sieci telefonicznej m. st. Warszawy P.A.S.T. Warszawskiej Sieci Okręowej P.P.T.T. rok 1939/1940, Warszawa 1938.

Spis abonentów warszawskiej sieci telefonów Polskiej Akcyjnej Spółki Telefonicznej rok 1937/38, Warszawa 1937.

Spis abonentów warszawskiej sieci telefonów Polskiej Akcyjnej Spółki Telefonicznej rok 1938/39, Warszawa 1938.

Stachiewicz P., „Parasol”. Dzieje oddziału do zadań specjalnych Kierownictwa Dywersji Komendy Głównej Armii Krajowej, Warszawa 1984.

Strzembosz T., Akcje zbrojne podziemnej Warszawy 1939-1944, Warszawa 1983.

Strzembosz T., Oddziały szturmowe konspiracyjnej Warszawy 1939-1944, Warszawa 1983.

Szyprowski B., Sąd Kapturowy przy Komendzie Głównej Związku Walki Zbrojnej w Warszawie (sierpień 1940 r. - listopad 1941 r.). Podziemie w walce ze zdrajcami Rzeczypospolitej, Warszawa 2016.

Szyprowski B., Wojskowy wymiar sprawiedliwości Armii Krajowej w czasie okupacji niemieckiej [w:] Porządek publiczny i bezpieczeństwo w okupacyjnej Warszawie, red. W. Spałek, Warszawa 2018.

Śliwicki Z., Meldunek z Pawiaka, Warszawa 1974.

Wanat L., Za murami Pawiaka, Warszawa 1985.

Witkowski H., Kedyw Okręgu Warszawskiego Armii Krajowej w latach 1943-1944, Warszawa 1985.

Wysoczyńska K., Zofia Franio. W służbie ojczyźnie, w służbie człowiekowi, Gdańsk 2018.

Urzędowa książka telefoniczna dla Dystryktu Warschau wedtug stanu z dnia 1 VIII 1942 r., Deutsche Post Osten 1942.

Urzędowy spis lekarzy, lekarzy-dentystów, farmaceutów, felczerów, pielęgniarek, położnych, uprawnionych i samodzielnych techników dentystycznych oraz wykazy: aptek, szpitali, ubezpieczalni społecznych, ośrodków zdrowia, przychodni 
samodzielnych oraz centrali i filii Państwowej Szkoły Higieny, cz. III: Farmaceuci, Warszawa 1939.

\section{Prasa}

„Agencja Prasowa”, 25 V 1944, nr 21 (214).

„Biuletyn Informacyjny”, 25 V 1944, nr 21 (228).

"Czas”, 6 V 1938, nr 123.

„Dziennik Zarządu Miejskiego w mieście stołecznym Warszawie”, 24 III 1939, nr 24.

„Kurier Warszawski”, 4 IX 1938, nr 242.

„Kurier Warszawski”, 6 II 1936, nr 36.

„Nowy Kurier Warszawski”, 28-29 VIII 1943, nr 204.

„Opiekun Społeczny. Miesięcznik Poświęcony zagadnieniom służby społecznej stolicy" 1938, $\mathrm{nr} 10$ (25).

„Rzeczpospolita Polska”, 28 V 1944, nr 7 (79).

\section{Strony internetowe}

Edward Madej, http://www.muzeum-niepodleglosci.pl/pawiak/kartoteka-online/?id=14201 (dostęp 25 IX 2019).

Informacja o więźniach, http://auschwitz.org/muzeum/informacja-o-wiezniach/ (dostęp 10 i 27 IX 2019).

Irena Kalinowska, http://www.muzeum-niepodleglosci.pl/pawiak/kartoteka-online/?id=11640 (dostęp 25 IX 2019).

Irena Popławska, http://www.muzeum-niepodleglosci.pl/pawiak/kartoteka-online/?id=25991 (dostęp 27 IX 2019).

Jadwiga Darmaszek-Sasiak, https://www.1944.pl/powstancze-biogramy/jadwigadarmaszek,7509.html?fbclid=IwAR3CpMPC8eveBjhORkDg9YvvvKtAxIeODCLVMsYKwrGqMy4FzZuHExUDTdA (dostęp 17 IX 2019).

Jadwiga Kuberska, http://www.muzeum-niepodleglosci.pl/pawiak/kartoteka-online/?id=17660 (dostęp 25 IX 2019).

Janina Kuberska, https://www.geni.com/people/Janina-Kuberska/600000005418 3018945 (dostęp 14 IX 2019).

Janina Kuberska, http://www.muzeum-niepodleglosci.pl/pawiak/kartoteka-online/?id=17661 (dostęp 25 IX 2019).

Jerzy Kleczkowski, http://www.muzeum-niepodleglosci.pl/pawiak/kartoteka-online/?id=14200 (dostęp 25 IX 2019).

Konstancja Darmaszek, http://www.nekrologi-baza.pl/zlista/67 (dostęp 10 IX 2019).

Königsberg W., Mieczysław Darmaszek - konfident zastrzelony przez kobiety, http://www.polska-zbrojna.pl/home/articleshow/22059?t=Mieczyslaw-Darmaszek-konfident-zastrzelony-przez-kobiety\# (dostęp 10 IX 2019).

Königsberg W., Zabójcze dziewczyny z AK. Likwidacja Mieczysława Darmaszka, https://ciekawostkihistoryczne.pl/2017/10/23/zabojcze-dziewczyny-z-ak-likwidacja-mieczyslawa-darmaszka/\#3 (dostęp 10 IX 2019).

Maria Kuberska, http://www.muzeum-niepodleglosci.pl/pawiak/kartoteka-online/?id=17662 (dostęp 25 IX 2019). 
Maria Popławska, http://www.muzeum-niepodleglosci.pl/pawiak/kartoteka-online/?id=25992 (dostęp 27 IX 2019).

http://www.nekrologi-baza.pl/?page_id=1149\&paged=5670 (dostęp 14 IX 1939).

Rozmowa Małgorzaty Rafalskiej-Dubek z Alicja Pniewska-Sieciechowicz,

9 VII 2012 r., https://www.1944.pl/archiwum-historii-mowionej/alicja-pnie wska-sieciechowicz,2912.html (dostęp 12 IX 2019).

Rozmowa Pauliny Jędrzejczak z Kwieta Kurkowską-Bondarecka, 8 XII 2010 r.

i 14 XII 2010 r., https://www.1944.pl/archiwum-historii-mowionej/kwieta-kurkowska-bondarecka,2336.html (dostęp 12 IX 2019).

Stanisław Popławski, http://www.muzeum-niepodleglosci.pl/pawiak/kartoteka-online/?id=26196 (dostęp 27 IX 2019).

Teresa Krassowska [w:] Encyklopedia Medyków Powstania Warszawskiego, https:// lekarzepowstania.pl/osoba/teresa-krassowska-ps-joanna/ (dostęp 13 IX 2019).

Zygmunt Popławski, http://www.auschwitz.org/muzeum/informacja-o-wiezniach/ (dostęp 27 IX 2019).

Wincenty Darmaszek, https://www.1944.pl/powstancze-biogramy/wincenty-darmaszek,7510.html?fbclid=IwAR28vU_YFJQXV4v0iUnQqoxHs16tCAPsp-z8rdYKKDONm0t81OfFeJM2I_4 (dostęp 17 IX 2019).

Inne

Informacja Zarządu Cmentarza Bródnowskiego w Warszawie, 24 IX 2019 r., w zbiorach autora.

Zdjęcie grobu Janiny Kuberskiej, w zbiorach autora.

Zdjęcie grobu Konstancji Darmaszek, w zbiorach autora.

\section{STRESZCZENIE}

\section{Bartłomiej Szyprowski, Aresztowanie Jadwigi Kuberskiej „Mei” i Ireny Kalinowskiej „Ludki” oraz likwidacja konfidenta Mieczysława Darmaszka}

Prezentowany artykuł poświęcony jest przedstawieniu sprawy likwidacji konfidenta niemieckiego Mieczysława Darmaszka, wykonanej przez kobiety - żołnierzy Kobiecych Patroli Minerskich Kierownictwa Dywersji Okręgu Warszawskiego AK. Autor prezentuje sylwetkę Mieczysława Darmaszka, okoliczności jego działalności konfidenckiej oraz uwarunkowania wykonania likwidacji. Ponadto artykuł podejmuje próbę wyjaśnienia nieścisłości dotyczących aresztowania rodziny Kuberskich oraz osób przebywających w ich domu, a także analizy od strony prawnej kwestii, czy była to likwidacja prewencyjna czy też wydano w tej sprawie wyrok sądu podziemnego.

Słowa kluczowe: Armia Krajowa, sądownictwo podziemne, Mieczysław Darmaszek, Jadwiga Kuberska „Mea”, Maria Kuberska, Jerzy Kleczkowski „Jurek”, Edward Madej „Felek”, Irena Bredel „Alina”, Elżbieta Ostrowska „Justyna”, konfidenci 


\section{SUMMARY}

\section{Bartłomiej Szyprowski, The Arrest of Jadwiga Kuberska "Mea” and Irena Kalinowska „Ludka” and the Elimination of Informer Mieczysław Darmaszek}

The article presents the case of the elimination of the German informer Mieczysław Darmaszek, carried out by female soldiers of the Women Mining Patrols of the Directorate of Diversion in the Home Army District of Warsaw. The author presents the character of Mieczysław Darmaszek and the circumstances of his informer activity and his elimination. Moreover, the article attempts to explain the inaccuracies concerning the arrest of the Kuberski family and the people staying at their house, as well as to analyze from the legal point of view, whether it was a preventive elimination or a verdict of the underground court had been issued.

Keywords: Home Army, underground judiciary, Mieczysław Darmaszek, Jadwiga Kuberska „Mea”, Maria Kuberska, Jerzy Kleczkowski „Jurek”, Edward Madej „Felek”, Irena Bredel „Alina”, Elżbieta Ostrowska „Justyna”, informers

\section{АННОТАЦИЯ}

\section{Бартломей Шипровски, Арест Ядвиги Куберской („Меи”) и Ирены Калиновской („Людки”), а также ликвидация информатора Мечислава Дармашка}

Данная статья посвящена вопросу ликвидации немецкого информатора Мечислава Дармашка, произведенной женщинами-солдатами Женского диверсионного патруля Управления Диверсии Варшавского округа Армии Крайовой. Автор представляет фигуру Мечислава Дармашка, обстоятельства его информаторской деятельности и обстоятельства проведения ликвидации. Кроме того, в статье предпринята попытка прояснить неточности, касающиеся ареста семьи Куберских и лиц, находящихся в их доме, а также юридический анализ вопроса, была ли это превентивная ликвидация или исполнение решение подпольного суда.

Ключевые слова: Армия Крайова, подпольная судебная система, Мечислав Дармашек, Ядвига Куберская „Меа”, Мария Куберская, Ежи Клечковски „Юрек”, Эдвард Мадей „Фелек”, Ирена Бредель „Алина”, Эльжбета Островская „Юстина”, информаторы 